\title{
Colorectal Cancer Immunotherapy: Options and Strategies
}

\author{
Nor Adzimah Johdi* and Nur Fazilah Sukor \\ UKM Medical Molecular Biology Institute (UMBI), National University of Malaysia, Bangi, Malaysia
}

Colorectal cancer is the third most common cancer in the world with increasing incidence and mortality rates globally. Standard treatments for colorectal cancer have always been surgery, chemotherapy and radiotherapy which may be used in combination to treat patients. However, these treatments have many side effects due to their non-specificity and cytotoxicity toward any cells including normal cells that are growing and dividing. Furthermore, many patients succumb to relapse even after a series of treatments. Thus, it is crucial to have more alternative and effective treatments to treat CRC patients. Immunotherapy is one of the new alternatives in cancer treatment. The strategy is to utilize patients' own immune systems in combating the cancer cells. Cancer immunotherapy overcomes the issue of specificity which is the major problem in chemotherapy and radiotherapy. The normal cells with no cancer antigens are not

OPEN ACCESS

Edited by: Alexandr Bazhin, LMU Munich University Hospital, Germany

Reviewed by:

Cristina Maccalli,

Sidra Medicine, Qatar

Douglas Clayton Palmer, National Cancer Institute (NCl), United States

*Correspondence: Nor Adzimah Johd adzimah@ppukm.ukm.edu.my

Specialty section:

This article was submitted to Cancer Immunity and Immunotherapy, a section of the journal

Frontiers in Immunology

Received: 10 January 2020

Accepted: 17 June 2020

Published: 18 September 2020

Citation:

Johdi NA and Sukor NF (2020) Colorectal Cancer Immunotherapy: Options and Strategies.

Front. Immunol. 11:1624. doi: 10.3389/fimmu.2020.01624 affected. The outcomes of some cancer immunotherapy have been astonishing in some cases, but some which rely on the status of patients' own immune systems are not. Those patients who responded well to cancer immunotherapy have a better prognostic and better quality of life.

Keywords: colorectal carcinoma, immunotherapy, FDA, T-cells, antibodies, cytokines, treatments

\section{INTRODUCTION}

Colorectal cancer (CRC) is the third most common cancer in the world with an incidence of $10.2 \%$ and a mortality rate of $9.2 \%$ of all cancers $(1,2)$. Approximately 1.8 million new cases and mortality of 0.88 million were recorded until 2018. From 1975 to 2013, CRC incidence rate increased from 10-15 cases per 100,000 population of Americans between the age of 20-49 years old (3). In developing countries such as Argentina, Brazil, and China, the incidence and mortality rate due to CRC increased around 20\% (4). Furthermore, the prognosis for patients with metastatic CRC remains poor with a median 5-year survival of only $18.5 \%$ in the United States and $27.7 \%$ in Europe $(1,2)$.

Standard conventional treatments for CRC are surgery, chemotherapy and radiotherapy. Depending on the localization and progression of the disease, these treatments can be used in combination (5-8). Total mesorectal excision (TME) through laparoscopic and transanal surgery approaches are often the options for localized cancer and whenever the tumor location is easy to access (9-11). However, complete removal of all cancer cells is often not possible. About 66 and $61 \%$ of stage II and III colon and rectal patients underwent further treatments with adjuvant chemotherapy and/or radiotherapy, respectively (12). These treatments have many side effects due to their unspecificity and cytotoxicity toward any cells that are growing and dividing $(13,14)$. Furthermore, 54\% of patients relapse even after neoadjuvant treatment (15). Thus, it is crucial to have more alternative and effective treatments to treat CRC patients. 
Cancer immunotherapy is one of the new alternatives in cancer treatment. In comparison to the standard treatment, this treatment manipulates and utilizes patients' own immune system in combating the cancer cells. The innate and adaptive immune responses are alerted to recognize the cancer cells and potentially eradicate the tumor (16-18). Many successes have been reported especially in hematological malignancies and solid tumors (19, 20). Cancer immunotherapy overcomes the issue of specificity which is the major problem in chemotherapy and radiotherapy. Cancer immunotherapy targets cancer antigens on the malignant cells specifically, alerts the immune systems to the presence of foreign substances and eradicates cancer through the concert of immune responses. The normal cells with no cancer antigens are not affected. The outcomes of some cancer immunotherapies have been astonishing in some cases, but some which rely on the status of patients' own immune systems are not. Those patients who responded well to cancer immunotherapy have a better prognostic and better quality of life.

Historically, cancer immunotherapy started in 1866 where notable tumor shrinkage was observed among cancer patients who were diagnosed with erysipelas caused by Streptococcus pyogenes $(21,22)$. Later in 1891, William Coley who is known as the 'Father of Immunotherapy' continued the discovery journey by introducing heat-inactivated Streptococcal bacteria (Coley's toxin) into unresectable osteosarcoma patients with the hope that any side effects produced from the infection would shrink the tumor (23). The approach was successful for a time. The patients who developed erysipelas went into spontaneous remission $(24,25)$. Following this, Coley improved the formulation by combining live and attenuated Streptococcus erysipelas and Bacillus prodigiosus (26). Around 1000 patients were successfully treated using this method. After 8 years of hard work, Coley's toxin was commercially available in 1899 (26). However, patients who underwent this treatment were exposed to extremely pathogenic bacteria. Furthermore, due to its unreproducible results, Coley's toxin was opposed by most of the health practitioners. Surgery remained the most preferable way to treat cancer during that time (27). captured scientists' attention with the new concept of tumorspecific antigens which was found in a mouse model. This was followed by theories on acquired immunological tolerance and immunosurveillance (28-30). A year later in 1957, another cancer immunotherapy approach using interferon- $\alpha$, a type of cytokine was introduced (31). The first cancer vaccine was also discovered during this era when 25 out of 114 (22\%) gynecologic cancer patients went into remission upon treatment with adjuvant tumor lysate (32). In the subsequent years, novel findings on the importance of $\mathrm{T}$ cells in cancer immunity made cancer immunotherapy more exciting, thus lead to the discovery of dendritic cells and natural killer cells' activities in mouse models (33-36). The first monoclonal antibody production using the hybridoma technique was also initiated in 1975 by Koehler and Milstein. They both were awarded a Nobel Prize in 1984 for this crucial finding which is widely used until today (37). Another significant finding in cancer immunotherapy was the discovery of the first immune checkpoint inhibitor namely
CTLA-4 in 1988, which led to its first clinical trial in the year 2000 and approval by United States Food and Drugs Administration (FDA) to treat metastatic melanoma in 2011 (38). The emergence of cancer immunotherapy continued until the FDA-approved Interleukin-2 and the first monoclonal antibody (mAbs), Rituximab were used as anti-cancer therapies in 1992 and 1997, respectively $(39,40)$.

In the 20th century, the FDA has approved various types of immunotherapeutic drugs including Sipuleucel-T, a cancer vaccine to treat castration-resistant prostate cancer in 2010 (41, 42). Five years later, the first oncolytic virotherapy agent known as T-VEC was approved in treating metastatic melanoma (43). The chimeric antigen receptor (CAR) T-cell therapy was also introduced to relapsed B-cell acute lymphoblastic leukemia and diffuse large B-cell lymphoma patients in 2017 and 2018 after getting approval $(44,45)$. In the same year, Tasuku Honjo and James Allison received their Nobel Prize in Physiology due to their significant contributions in discovering the immune checkpoint inhibitors, PD-1 and CTLA-4, respectively (46). Currently, with an increasing number of FDA approved single and combinational immunotherapeutic drugs over the years, the cancer immunotherapy field is continuously showing potential in treating various types of malignancies.

\section{IMMUNE CLASSIFICATION}

Cancer immunotherapies are classified based on the types of immune mechanisms that are involved either through passive or/and active mechanisms or based on antigen specificity (47). Passive immunotherapies are tumor-targeting mAbs, adoptive cell transfer (ACT) and oncolytic virotherapy while active immunotherapies are immunomodulatory mAbs, anticancer vaccines, immunostimulatory cytokines, inhibitor of immunosuppressive metabolism, pattern recognition receptor (PRR) agonists, immunogenic cell death inducer and other nonspecific immunotherapeutic agents.

\section{Monoclonal Antibodies (mAb)}

Monoclonal antibodies (mAbs) are immunoglobulin molecules, which are made up of antigen-binding fragments that are connected to a constant region with two identical light and heavy chains. The light chains are made up of one variable and one constant domain while the heavy chains consist of one variable and three constant domains (48). There is also a special region within the variable domain with 3 loops known as the complementarity determining region (CDR) (48).

Initially, the hybridoma technique (49) and phage display (50) were used in producing murine mAbs in the laboratories. With advanced technologies, three types of antibody-engineered mAbs are produced using the same technique, namely chimeric, humanized and human monoclonal antibodies. Chimeric mAbs consist of cloned human amino acids at the constant domain whereas mouse amino acids are located at the variable domain. Chimeric mAbs can be produced by directly joining the variable region immunoglobulin of selected mouse hybridoma into the human constant region through in vitro cell-based technology 
(51). Examples of FDA approved chimeric mAbs are Rituximab that is used to treat Non-Hodgkin Lymphoma, Cetuximab to treat colorectal cancer and Dinutuximab that is used among neuroblastoma patients (52). On the other hand, humanized mAbs are generated through the addition of murine CDR into the human's variable and constant domain through CDR grafting (53). Some of the FDA approved humanized mAbs are Trastuzumab used to treat breast cancer, Alemtuzumab to treat chronic myeloid leukemia and Bevacizumab to treat colorectal cancer (52). The third type of mAbs is the human mAbs which are produced when the whole $\mathrm{mAbs}$ are made up from human amino acids (54). This may be done through the preference of human antibody fragments from human hybridomas and in vitro libraries by transgenic mice (48). Human mAbs that are approved by FDA for cancer treatments are Panitumumab to treat colorectal cancer, Ofatumumab to treat chronic lymphocytic leukemia and Ramucirumab to treat gastric cancer (52).

Unlike polyclonal antibodies that bind to multiple epitopes, mAbs have a monovalent affinity which makes them bind to an epitope of antigens (55). The mAbs can recognize and bind specifically to tumor antigens of tumor-specific antigen (TSA) (56) or tumor-associated antigen (TAA) (57) that are present on cancer cells surface (Figure 1). TSAs are a group of mutated proteins due to somatic mutations and relatively are restricted to tumor cells (58). Their specificity in tumor cells makes them a good candidate for immunotherapy. One of the good examples of a TSA is the mutated $\mathrm{p} 53$ protein that is present in many cancer cells including colorectal cancer. As a result, the p53 synthetic long peptide vaccine was designed to treat metastatic CRC patients (59). The results show that around $90 \%$ of the respondents treated with this vaccine produced $\mathrm{p} 53$-specific- $\mathrm{T}$ cell response with low-grade toxicity suggesting that p53 is indeed one of the attractive TSAs in cancer immunotherapy (59).

In contrast, TAAs have differentially expressed proteins that are present in both malignant and non-malignant cells. Although TAAs are expressed on normal cells, their expression

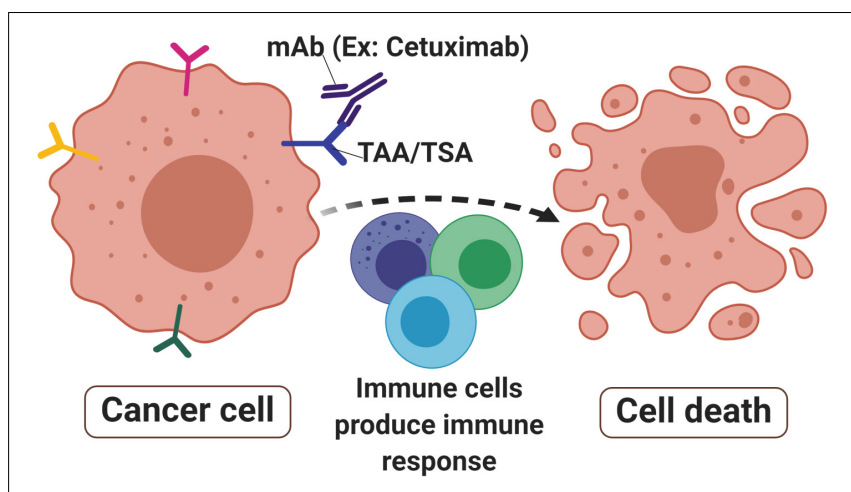

FIGURE 1 | Monoclonal antibodies in cancer. Monoclonal antibodies (mAbs) such as Cetuximab are designed to target tumor-associated antigens (TAAs) or tumor-specific antigens (TSAs) that are abundant in cancer cells surface. The signals produced by receptor activities mediated immune cells toward malignant sites thus produced immune responses that lead to cell death to eradicate the tumor. on malignant cells has a unique characteristic resulting in specific immunogenicity (60). Nevertheless, because the antigens are also expressed on the normal cells, they may induce autoimmunity in the host (61). To overcome this, the self-antigen concept suggests that the self-reactive $\mathrm{T}$ cells are to be deactivated, therefore increasing their specificity in targeting the unique TAA on tumor cells (62). Furthermore, cancer vaccines must have a high tendency to specifically bind to tumor antigens and effectively kill them with minor adverse effects on normal cells. TAAs can be divided into four categories based on their expression pattern namely cancer-testis antigens (CTA), differentiation antigen, oncofoetal antigen and overexpressed antigens (62). CTA are aberrantly expressed protein in cancer and testis tissues with restricted expression in other normal tissues (63). A widely studied CTA in CRC is the melanoma-associated antigen (MAGE) group, particularly MAGE-A (64), MAGE-A12 (65), and MAGE-A3 (66) variants. Differentiation antigens are expressed during cell differentiation stages such as Mucin 1 glycoprotein (MUC1) (61) and epithelial cell adhesion molecule (EpCAM) (67). These antigens may not create major side effects as they are tissue-specific and are only expressed during the cell differentiation stage (62). Oncofoetal antigens such as 5T4 (68, 69) and carcinoembryonic antigens (CEA) (70) are found in fetal tissues during its development as well as in several malignancies including ovarian, colorectal and breast cancers. Overexpressed antigens are huge, various groups of common proteins that can be found in both malignant and normal cells. However, they are highly expressed in malignant cells compared to the normal which thus have potential as an immunotherapeutic target (71). Some of the extensively studied overexpressed antigens in CRC are epidermal growth factor receptor (EGFR) (72), coiled-coil domain containing 34 (CCDC34) (73) and RAS-related protein (Rab-1A) (74). The binding of mAbs to TSA or TAA produces molecular signals to immune cells such as T cells, B cells and natural killer cells. This further initiates and activates receptors activities that lead to apoptosis and tumor-killing $(75,76)$.

The two major types of mAbs are tumor-targeting $\mathrm{mAbs}$ and immunomodulatory mAbs.

\section{Tumor-Targeting mAbs}

One of the passive immunotherapies is tumor-targeting $\mathrm{mAbs}$ and it is the most commonly mAbs used in treating hematological malignancies and other solid tumors. There are $76 \mathrm{mAbs}$ that are approved by the European Medical Agency (EMA) and Food Drugs Administration (FDA) for therapeutic use (status 2017) (77). Table 1 listed the top 10 current EMA and/or FDA approved mAbs that are used for cancer treatments.

\section{Immunomodulatory mAbs}

One of the common immunomodulatory mAbs is immune checkpoint inhibitors (ICIs). The ICIs are used to target and/or block immune checkpoints protein ligands on $\mathrm{T}$ cells surfaces or other immune cell subpopulations in restoring immune function. The immune checkpoints serve as key regulators that serve as an immune brake when there is sufficient immune response. However, in cancer, there is high activation and overexpression of immune checkpoints leading to suppression of anti-tumor 
TABLE 1 | The top 10 current EMA and/or FDA approved mAbs that are used for cancer treatments $(78,79)$.

\begin{tabular}{|c|c|c|c|c|c|c|c|}
\hline No. & Trade name & $\begin{array}{l}\text { International } \\
\text { Non-proprietary } \\
\text { Name (INN) }\end{array}$ & Target & Type & $\begin{array}{l}\text { EMA approval } \\
\text { (Year) }\end{array}$ & $\begin{array}{c}\text { FDA approval } \\
\text { (Year) }\end{array}$ & Cancer \\
\hline 1 & Bavencio ${ }^{\circledR}$ & Avelumab & PD-L1 & Human $\lg \mathrm{G} 1 / \mathrm{K}$ & Not approved & 2017 & $\begin{array}{l}\text { Metastatic Merkel cell } \\
\text { carcinoma }\end{array}$ \\
\hline 2 & Imfinzi® ${ }^{\circledR}$ & Durvalumab & PD-L1 & Human lgG1/K & Not approved & 2017 & Metastatic urothelial carcinoma \\
\hline 3 & Lartruvo & Olaratumab & PDGFR- $\alpha$ & Human IgG1 & 2016 & 2016 & Sarcoma \\
\hline 4 & Darzalex ${ }^{\circledR}$ & Daratumumab & CD38 & Human IgG1/K & 2016 & 2015 & Multiple myeloma \\
\hline 5 & Empliciti & Elotuzumab & SLAMF7 & Human IgG1 & 2016 & 2015 & Multiple myeloma \\
\hline 6 & Portrazza & Necitumumab & EGFR & Human IgG1 & 2016 & 2015 & Non-small cell lung cancer \\
\hline 7 & Tecentriq $^{\circledR}$ & Atezolizumab & PD-L1 & Human IgG1 & Not approved & 2016 & $\begin{array}{l}\text { Metastatic non-small cell lung } \\
\text { cancer }\end{array}$ \\
\hline 8 & Opdivo & Nivolumab & PD-1 & Human lgG4 & 2015 & 2015 & $\begin{array}{l}\text { Non-small cell lung carcinoma; } \\
\text { renal cell Hodgkin diseases, } \\
\text { melanoma }\end{array}$ \\
\hline 9 & Unituxin & Dinutuximab & GD2 & Human lgG1/K & $\begin{array}{l}2015 \text { (but has been } \\
\text { withdrawn) }\end{array}$ & 2015 & Neuroblastoma \\
\hline 10 & Blincyto ${ }^{\circledR}$ & Bevacizumab & CD19 & BiTEs & 2015 & 2014 & $\begin{array}{l}\text { Precursor cell lymphoblastic } \\
\text { leukemia-lymphoma }\end{array}$ \\
\hline
\end{tabular}

immune response that favors malignant cell proliferation and spread $(80,81)$.

The most widely studied immune checkpoint targets are programmed cell death 1 (PD-1) and cytotoxic T lymphocyte antigen 4 (CTLA4) due to their overexpression and abundance in various solid tumors and hematological malignancies (82). Nevertheless, other checkpoints are currently being studied for their potential roles in tumor immunity regulation such as lymphocyte activation gene-3 (LAG-3), T cell immunoglobulin3 (TIM-3), and T cell immunoglobulin and ITIM domain (TIGIT) (83-86).

In colorectal cancer, three FDA-approved ICIs drugs are targeting PD-1 and CTLA-4 (Table 2). However, ICI treatment efficiency is influenced by the microsatellite instability (MSI) status in each CRC patient $(87,88)$. MSI status is determined through immunohistochemistry staining and polymerase chain reaction targeting 5 MSI markers of BAT25, BAT26, D2S123, D5S346, and D17S250 (89). CRC patients are divided into three groups based on their mutation patterns of microsatellite instability-high (MSI-H), microsatellite instability-low (MSI-L), and microsatellite stable (MSS) $(90,91)$. ICI drugs targeting PD-1 and CTLA4 are more potent on metastatic CRC patients with MSI-H due to its higher tumor mutation burden (TMB). High TMB is positively correlated with high neo-antigen load thus increasing tumor immunogenicity (92). The majority of CRC patients with MSI-H benefited with this immunotherapy where the disease control rate was $80 \%$ using the combination of Nivolumab and Ipilimumab compared to patients having microsatellite stable (93).

\section{Cytotoxic T-lymphocyte-associated antigen 4 (CTLA-4)}

Cytotoxic T-lymphocyte-associated antigen 4 (CTLA-4) is one of the immune checkpoints that serve as co-inhibitory receptors on the $\mathrm{T}$ cell surface (38). The role of CTLA-4 in cancer immunotherapy was discovered through antibody generation that specifically targets the CTLA-4 glycoprotein (94). Under
TABLE 2 | FDA approved immune checkpoint inhibitors drugs for colorectal cancer treatments (78).

\begin{tabular}{|c|c|c|c|c|}
\hline Trade name & $\begin{array}{l}\text { International } \\
\text { Non- } \\
\text { proprietary } \\
\text { Name (INN) }\end{array}$ & Target & $\begin{array}{l}\text { FDA } \\
\text { approval } \\
\text { date }\end{array}$ & Cancer \\
\hline Keytruda $^{\circledR}$ & Pembrolizumab & PD-1 & $\begin{array}{l}23 \text { May } \\
2017\end{array}$ & $\begin{array}{l}\text { Unresectable or } \\
\text { metastatic mismatch } \\
\text { repair deficient (dMMR) } \\
\text { and microsatellite } \\
\text { instability-high (MSI-H) } \\
\text { CRC }\end{array}$ \\
\hline Opdivo ${ }^{\circledR}$ & Nivolumab & PD-1 & $\begin{array}{l}1 \text { August } \\
2017\end{array}$ & $\begin{array}{l}\text { Metastatic mismatch } \\
\text { repair deficient (dMMR) } \\
\text { and microsatellite } \\
\text { instability-high (MSI-H) } \\
\text { CRC }\end{array}$ \\
\hline Yervoy $^{\circledR}$ & Ipilimumab & CTLA-4 & $\begin{array}{l}10 \text { July } \\
2018\end{array}$ & $\begin{array}{l}\text { Used in combination } \\
\text { with nivolumab } \\
\text { Metastatic mismatch } \\
\text { repair deficient (dMMR) } \\
\text { and microsatellite } \\
\text { instability-high (MSI-H) } \\
\text { CRC }\end{array}$ \\
\hline
\end{tabular}

normal circumstances, $\mathrm{T}$ cell antigen receptor stimulation is regulated by $\mathrm{CD} 28$ co-stimulatory and CTLA- 4 co-inhibitory signals (95). When there is an attack from a foreign substance, CD28 co-stimulatory signals increase to stimulate the $\mathrm{T}$ cell antigen receptors which further activate the downstream immune signaling (96). When the foreign substance has been cleared, CTLA-4 co-inhibitory signals are activated to stop immune signaling and thus prevent excessive immune responses or autoimmunity. Unlike CD28, CTLA-4 acts as negative regulatory feedback in T-cell stimulation. It switches off the $\mathrm{T}$ cell activity during priming and thus inhibits $\mathrm{T}$ cell activation and leads to antigenic tolerance. Hence, both $\mathrm{CD} 28$ co-stimulatory and 
CTLA-4 co-inhibitory signals are critical in maintaining $\mathrm{T}$ cell homeostasis and self-tolerance (97-99). However, there are some instances where CTLA- 4 co-inhibitory signals are constitutively high and this can halt T cell activation (100). Such scenarios are seen in many cases of cancers and suppressor $\mathrm{T}$ cells such as $\mathrm{T}$ regulatory cells, suggesting the reason for lack of immune responses in cancer patients $(101,102)$. CTLA-4 protein is homologous to CD28 protein and has a higher binding affinity toward CD80 and CD86 on major histocompatibility complex (MHC) (Figure 2). This has been the avenue in immunotherapy in targeting CTLA-4 protein expression to stimulate the patient's own $\mathrm{T}$ cell immune response. Many immune checkpoint inhibitor drugs are targeting CTLA-4 that is designed to bind and block this protein, thus allow CD28 binding to MHC and stimulate T cell immune response, activate downstream immune signaling and destroy the malignant cells $(103,104)$.

\section{Programmed death 1 receptor and its ligand (PD-1/PD-L1)}

Programmed death 1 (PD-1; CD279) is a novel member of the immunoglobulin gene superfamily (IgSF) with restricted expression in the thymus of mice (105). The PD-1 gene was first discovered in apoptosis gene screening and was shown to be involved in apoptosis of interleukin-3 (IL-3)-deprived LyD9 (a murine hematopoietic progenitor cell line) and stimulated 2B4.11 (a murine T-cell hybridoma) (105).

In humans, the PD-1 (PDCD1) gene is located at $2 \mathrm{q} 37.3$ which encodes for PD-1 proteins (106). This protein is a type I transmembrane glycoprotein with a size of $50-55 \mathrm{kDa}(107)$. PD-1 is expressed in various immune cells such as CD4 and CD8 T cells, B cells, macrophages, dendritic cells and tumorinfiltrating lymphocytes (TILs) $(108,109)$. It functions as an immune checkpoint that balances the peripheral tolerance and regulates T-cell responses under normal conditions (110).

Programmed death 1 binds to two ligands, PD-L1 (CD274; B7-H1) and PD-L2 (CD273; B7-DC) with differential expression (111). This binding activates PD-1: PD-L1/L2 pathway which then mediates potent inhibitory signals to hinder the proliferation and function of $\mathrm{T}$ effector cells and have inimical effects on antiviral and antitumor immunity (112).

Similar to CTLA-4, the main role of PD-1/PDL1 interaction (PD-1 pathway) under normal conditions is as a brake for immune response in which the pathway can limit T-cell effector responses. One of the ways is through enhancing immunosuppressive regulatory cells (Tregs) development, thus prevent over-activation of the immune response in human peripheral tissues (113). This immune homeostasis is important in protecting us from autoimmune and severe inflammation.

However, this is not always the case in cancer. Overexpression of PD-1 is observed that leads to constant PD-1 (on the T cell surface) binding to its ligand, PDL1 (on the cancer cells). As a result, PD1/PDL1 signals are constitutively high, suppress the activation of $\mathrm{T}$ cells and cause antigenic tolerance. This allows immune cell evasion by cancer cells which then support the high tumor proliferation rate $(114,115)$. Therapeutic strategies targeting PD1/PDL1 pathways have resulted in many checkpoint inhibitors that function to interfere with PD-1/PDL1 binding through competitive binding and lead to restoring effector $\mathrm{T}$ cells activity in cancer patients. Drugs inhibitors were designed to bind and block PD1/PDL1 binding to restore effector $\mathrm{T}$ cells activation, proliferation, function and downstream immune signaling to destroy the malignant cells (104).

To date, there are five FDA approved PD-1 inhibitor drugs for various cancers $(103,116)$ (Table 3$)$. The first FDA approved PD-1 inhibitor drug was Pembrolizumab (Keytruda ${ }^{\circledR}$ ), a humanized monoclonal IgG4 antibody, used in treating melanoma (78). Phase I trial of the drug was tested in solid tumor and hematological malignancies patients. Results show that Pembrolizumab was well tolerated among multiple solid tumors patients (117). There was a significantly longer survival rate with minimum side effects among advanced non-small cell lung cancer (NSCLC) with high PDL1 expression compared to patients treated with platinum-based chemotherapy (118).

In CRC patients, Pembrolizumab shows significant benefit to the mismatch-repair deficient or microsatellite instability-high CRC patients (dMMR/MSI-H). Results show the progressionfree survival rate up to $78 \%$ compared to mismatch-repair proficient, microsatellite stable (pMMR/MSS) patients of $11 \%$ (119). Another successful PD-1 inhibitor is Nivolumab $\left(\right.$ Opdivo $^{\circledR}$ ) that shows durable responses among the dMMR metastatic CRC (mCRC) cohort of patients. Approximately, 69\% of these patients have 12 months of overall survival (OS) (120). Interestingly, a combination of Nivolumab with Ipilimumab (a CTLA4-targeting drug) demonstrates a higher response rate of up to $94 \%$ in these patients. This suggests that the combination of immune checkpoints therapy can greatly improve the efficacy of the treatment for dMMR/MSI-H mCRC patients (93).

\section{Adoptive Cell Transfer (ACT)}

Adoptive cell transfer is a cell-based therapy that uses cells either from the patient (autologous transfer) or other donors (allogeneic transfer) to improve immune function (121). There are 3 methods for the ACT; use of tumor-infiltrating lymphocytes (TILs), insertion of chimeric antigen receptor (CAR), and modification of T cell receptors (TCR) (122).

Adoptive cell transfer that uses TILs (ACT-TIL) was first successfully observed in $60 \%$ of metastatic melanoma patients who had not been treated with interleukin-2 (IL-2) and $40 \%$ of non-respondents IL-2 treatments which resulted in cancer regression (123). However, major drawbacks with ACTTIL using patients' own TIL was a limitation in generating tumor-specific $\mathrm{T}$ cells. This leads to the development of another approach using patients' own genetically engineeredTCR. Approximately 13\% (2 out of 15) metastatic melanoma patients benefited from this type of ACT with high sustained engineered $\mathrm{T}$ cells level were observed after a year of infusion (124). A few years later, ACT uses a better method of CAR insertion. This was shown to be safe to use among a cohort of clear cell renal cell carcinoma (ccRCC) and ovarian cancer patients with no toxicity observed although only two and none of these patients respond toward the treatment, respectively $(125,126)$.

CAR-T cells consist of antibody variable fragments specific to the antigen of interest that are fused to the isolated 


\section{A DEACTIVATED T CELL}

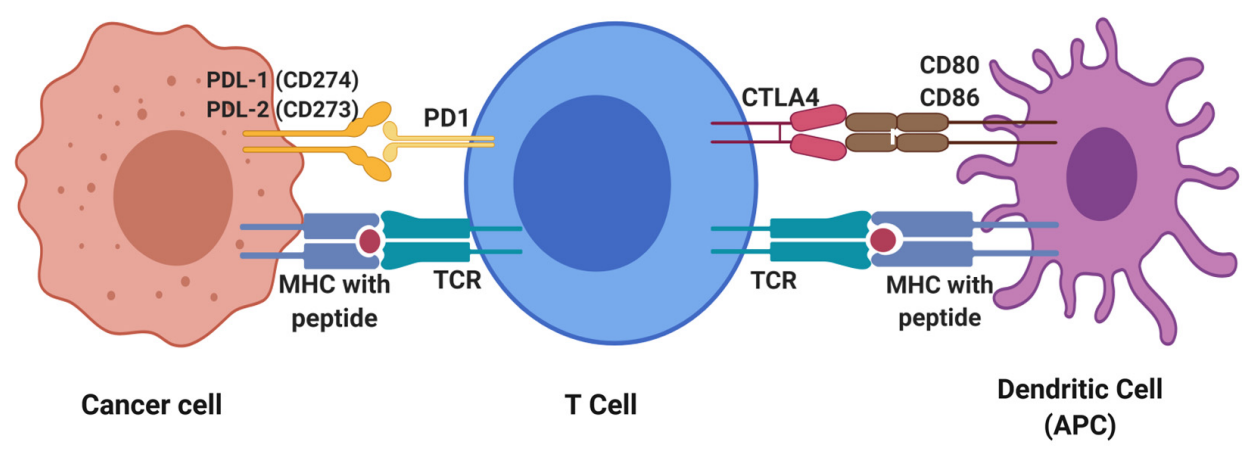

B ACTIVATED T CELL

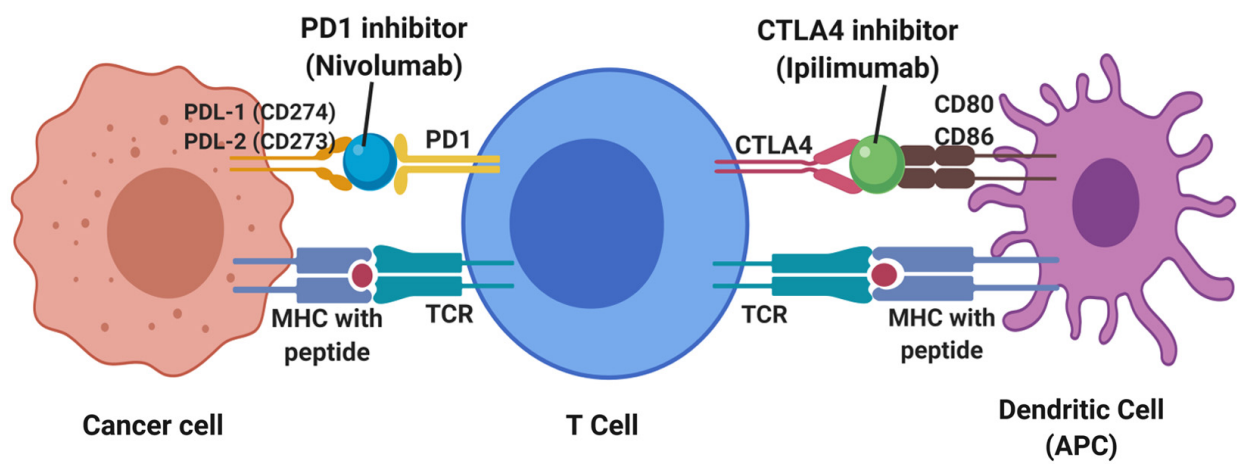

FIGURE 2 | Deactivated (A) and activated (B) T cell-based on immune checkpoint inhibitors mechanism. During resting of T cell (deactivated T cell), CTLA4 and PD1 receptors on T cell surface binds to CD80 and CD86 on the antigen-presenting cell (APC) such as dendritic cell and PDL-1 and PDL-2 on cancer cell, respectively, while T cell receptor (TCR) binds to major histocompatibility complex $(\mathrm{MHC})$ with the presence of peptide. Thus, no immune response triggered to kill cancer cells. $T$ cells will only be activated with the presence of blockade or inhibitor on CTLA4 and PD1 receptors. Hence, a CTLA4 inhibitor known as Ipilimumab and PD1 inhibitor of Nivolumab functioned to block those receptors and elicit immune response thus leading to the apoptosis of cancer cells.

patient's or donor's T cells (127). In the CAR approach, $\mathrm{T}$ cells are isolated from a patient (autologous) or HLAmatched donor (allogeneic), cultured through ex vivo and genetically modified through the insertion of the chimeric antigen receptor (CAR) onto the T cells as CAR-T cells (128). The modified ex vivo CAR-T cells are re-infused back into the patient and monitored. The modifications are necessary for enhancing the $\mathrm{T}$ cells' ability to recognize the antigen of interest and avoid the major histocompatibility complex restriction recognition. This leads to highly targeted antigen recognition and allows active trafficking to tumor sites, in vivo expansion and long-term persistence. Usually, CAR-T cells are engineered toward tumor-associated antigens (TAAs) such as CD19 in diffuse large B cell lymphoma (DLBCL) (129), interleukin 13 receptor alpha-2 (IL13R $\alpha 2$ ) (130) and epidermal growth factor variant III (EGFRvIII) in glioblastoma (131) and carcinoembryonic antigen (CEA) in colorectal cancer (132) to promote cytotoxicity and apoptosis (Figure 3 ). The advantage of CAR-T cells is their specificity in targeting cell surface
TAA in an MHC-independent manner. This allows more patients to be treated without the need for MHC-specific treatment. In addition, co-stimulatory domains such as CD28 or 4-1BB (CD137) can be added to improve CAR-T cells' proliferation and survival rate in vivo, thus enhancing the antitumor activity of CAR-T cells $(133,134)$. Furthermore, the $\mathrm{T}$ cell responses produce memory cells that help to preserve the immunotherapeutic effect for several years even after treatments $(135,136)$.

Like many other methods, ACT comes with some limitations. This approach is highly technical and economically challenging for both the industry and patients due to the need to generate tumor-specific lymphocytes for each patient. Secondly, the patient who is receiving the allogeneic transfer is often exposed to the danger of graft-versus-host-disease (GvHD). Furthermore, toxicity is the main issue when targeting antigenic targets such as TAA which are also expressed on normal tissues but are overexpressed on the tumor. An example of these cross-reactivities was seen in CAR-T cells targeting 
TABLE 3 | FDA approved PD-1 and PDL-1 inhibitor drugs in various types of cancer immunotherapy $(78,116)$.

\begin{tabular}{|c|c|c|c|}
\hline Agent & Target & $\begin{array}{l}\text { Commercial } \\
\text { name }\end{array}$ & $\begin{array}{l}\text { Date of FDA approval/types } \\
\text { of cancer treated }\end{array}$ \\
\hline \multirow[t]{7}{*}{ Pembrolizumab } & PD-1 & Keytruda ${ }^{\circledR}$ & 9/2014: Melanoma \\
\hline & & & $\begin{array}{l}\text { 10/2015: Non-small cell lung } \\
\text { cancer }\end{array}$ \\
\hline & & & $\begin{array}{l}\text { 8/2016: Head and neck } \\
\text { squamous cell carcinoma }\end{array}$ \\
\hline & & & 3/2017: Hodgkin lymphoma \\
\hline & & & 5/2017: Urothelial carcinoma \\
\hline & & & $\begin{array}{l}\text { 5/2017: MSI-H colorectal } \\
\text { cancer }\end{array}$ \\
\hline & & & 9/2017: Gastric cancer \\
\hline \multirow[t]{7}{*}{ Nivolumab } & PD-1 & Opdivo ${ }^{\circledR}$ & 12/2014: Melanoma \\
\hline & & & 11/2015: Renal cell carcinoma \\
\hline & & & 5/2016: Hodgkin lymphoma \\
\hline & & & $\begin{array}{l}\text { 11/2016: Head and neck } \\
\text { squamous cell carcinoma }\end{array}$ \\
\hline & & & 2/2017: Urothelial carcinoma \\
\hline & & & $\begin{array}{l}\text { 8/2017: MSI-H colorectal } \\
\text { cancer }\end{array}$ \\
\hline & & & $\begin{array}{l}\text { 9/2017: Hepatocellular } \\
\text { carcinoma }\end{array}$ \\
\hline \multirow[t]{2}{*}{ Atezolizumab } & PDL-1 & Tecentriq $^{\circledR}$ & 5/2016: Urothelial carcinoma \\
\hline & & & $\begin{array}{l}\text { 10/2016: Non-small cell lung } \\
\text { cancer }\end{array}$ \\
\hline \multirow[t]{2}{*}{ Avelumab } & PDL-1 & Bavencio ${ }^{\circledR}$ & 3/2017: Merkel cell carcinoma \\
\hline & & & 5/2017: Urothelial carcinoma \\
\hline Durvalumab & PDL-1 & Imfinzi ${ }^{\circledast}$ & 5/2017: Urothelial carcinoma \\
\hline
\end{tabular}

HLA-A*0201-restricted peptide in melanoma-associated antigen (MAGE)-A3. This approach had caused severe damage to gray matter in the brain as the TCR recognized a different but related epitope that was expressed at low levels in the normal brain cells (137). Another limitation is related to cytokine release syndrome (CRS), which is life-threatening toxicity that has been observed in the ACT. CRS refers to an elevated state of circulating level of cytokines, chemokines and other signaling proteins including interleukin 6 (IL-6) and interferon $\gamma$ as a result of tumor lysis. This, in turn, activates more immune cells and other immune signalings, leading to excessive immune responses and toxicities (138). Other side effects including neurological problems such as problems remembering words, difficulty in speaking, being less alert, hallucinations, seizures and coma. In many patients, these problems fade on their own in a few days, but some have died from these problems. Nevertheless, FDA approved ACT was listed for many hematological malignancies (Table 4) but most of the solid tumors are still undergoing clinical trials.

In CRC, CAR-T cells target carcinoembryonic antigens (CEA) and guanylyl cyclase C (GUCY2C) $(142,143)$ tumor-associated glycoprotein (TAG72) (144), epithelial cell adhesion molecule (EpCAM) (145), NK cell surface receptor ligands (NKG2DLs) such as major histocompatibility complex (MHC) class I-related chain A and B (MICA and MICB, respectively) and six unique long 16 binding protein (UL-BP1-6) (146). The CAR-T cell therapy can work effectively only if these targets are highly expressed in colorectal carcinoma tissues with low expression in other normal tissues. Normally, these molecules are present at low or undetectable levels on normal cells but rapidly appear on the surface of stressed, malignant transformed and infected cells. For example, therapeutic potential targeting CEA was observed with tumor regression and antigen specificity but with some CRS toxicity and severe colitis (143, 147, 148). These effects were due to the overexpression of CEA in both colorectal adenocarcinomas and several normal colonic mucosae of the gastrointestinal tract (149). Despite some of the drawbacks of CEA targeted CAR-T cell approaches, a phase I trial was performed among CEA + mCRC patients to evaluate its efficacy. Interestingly, there were no CAR-T related severe adverse events observed among all the 10 patients involved in this study (150). Furthermore, combination treatment between CEA-CAR-T cells in addition to recombinant human interleukin 12 (rh-IL12) in mouce models show effective and elevated anti-tumor activity of CAR-T cells among various types of solid tumors including CRC (151).

However, some limitations are encountered in effective targeting of solid tumors by CAR-T cells. This explains why CAR-T cells have not proceeded into commercialization and approval for solid tumors. One of the challenges is the efficient trafficking and infiltrating of solid tumors. The microenvironment of solid tumors contains an abundant fibrous matrix and immunosuppressive cells, which protects the tumor tissue and resists immune cell attack. This includes certain chemokines such as CXCL1, CXCL12, and CXCL5 that are secreted by the tumor cells to inhibit the effective delivery of the CAR-T cells $(152,153)$. Therefore, overcoming this hindrance is through engineering chemokine receptor (CXCL1 receptor) $\mathrm{T}$ cells. This has greatly drive CAR-T cells to migrate toward chemokines secreted-tumor cells (154). However, having the CXCL1 receptor- engineered T cells is not an ultimate solution. Even if the CAR-T cells successfully traffick and infiltrate the cancer cells, the nature of the tumor and environment themselves further inhibit the actions of the CAR-T cell. This refers to the architecture of the cancer cells such as extensive vascular leakage, poor integrity of tissue structure, hypoxia and low $\mathrm{pH}$. In hypoxic conditions, the acidic tumor microenvironment lacks the necessary essential amino acids. Thus, $\mathrm{T}$ cells are likely to experience anergy, exhaustion, senescence and stemness, making it a challenge to achieve the desired CAR-T cells tumor killing (155). Also, other immune suppressor cells such as T cells (Tregs), myeloid-derived suppressor cells (MDSCs) and tumor-associated macrophages are present in the tumor microenvironment that further inhibit the CAR-T cells from being activated and producing a response toward cancer cells. Furthermore, immune checkpoint receptors on tumor cells or immunosuppressive cells are able to inhibit $\mathrm{T}$ cells by binding to negative regulatory ligands on T cells. As an example, PD-L1 on the tumor cell surface binds to PD1 on T cells, which will inhibit CAR-T cell activation. Lastly, the tumor-derived inhibitory cytokines such as transforming growth factor- $\beta$ (TGF- $\beta$ ) are able to deter the function of CAR-T cells in killing the cancer cells. TGF- $\beta$ plays 


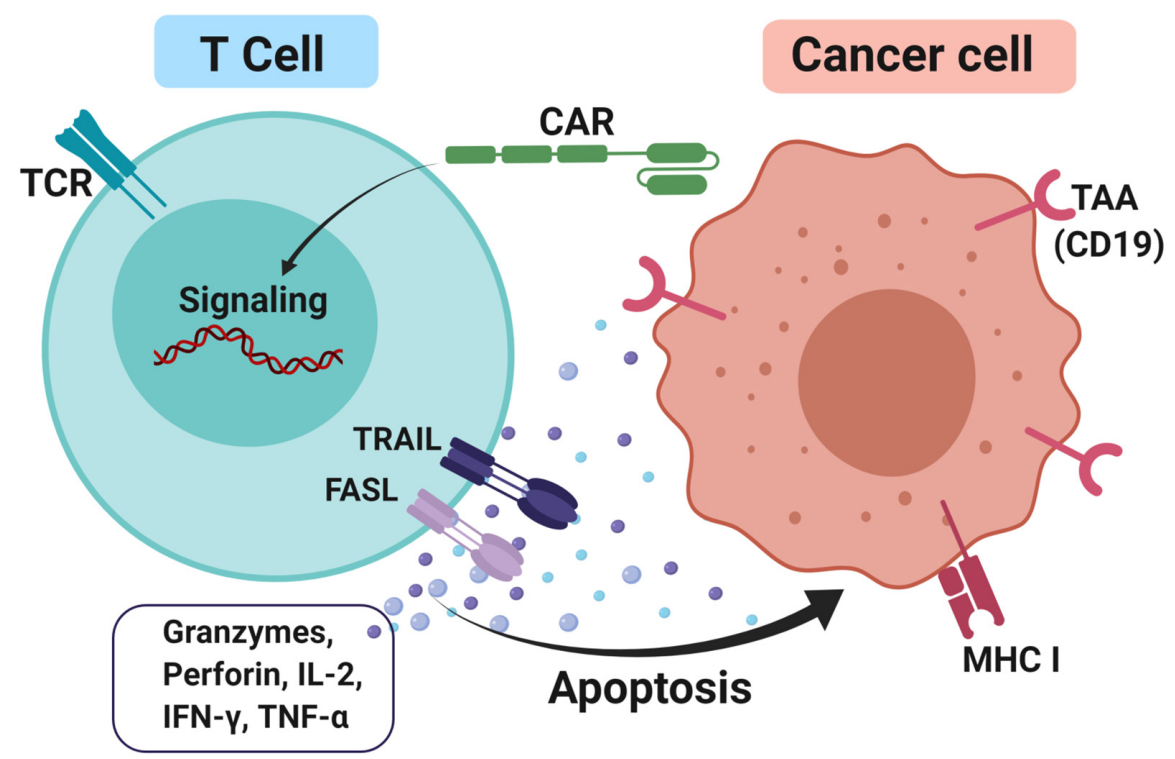

FIGURE 3 | CAR-T cells approach to treating cancer. T cells were firstly isolated either from the patient itself or HLA matched donor through apheresis. Next, the cells were cultured and a genetically modified chimeric antigen receptor (CAR) was inserted into it and these T cells are now known as CAR-T cells. This modification is necessary to enhance T cells' ability to recognize tumor-associated antigens (TAAs) such as CD19 and avoid the major histocompatibility complex class I (MHC I) restriction recognition on the cancer cell. Upon binding, FAS ligand (FASL) and TNF-related apoptosis-inducing ligand (TRAIL) promotes cytotoxicity by releasing effector cytokines and lead to cancer cell apoptosis.

TABLE 4 | FDA approved CAR T cells treatments in cancers (78).

\begin{tabular}{|c|c|c|c|c|c|}
\hline No. & Types of cancer & CAR T cells & Description & $\begin{array}{l}\text { FDA approval } \\
\text { date }\end{array}$ & References \\
\hline 1 & $\begin{array}{l}\text { B-cell acute } \\
\text { lymphoblastic } \\
\text { leukemia (B-ALL) } \\
\text { Diffuse large B-cell } \\
\text { lymphoma (DLBCL) }\end{array}$ & $\begin{array}{l}\text { Tisagenlecleucel } \\
\text { (Kymriah) }\end{array}$ & $\begin{array}{l}\text { CART19 product composed of } \\
\text { an extracellular CD19 targeting } \\
\text { scFv fused to CD137 and CD3z } \\
\text { intracellular signaling domains }\end{array}$ & 30th August 2017 & $(45,129,139,140)$ \\
\hline 2 & $\begin{array}{l}\text { Non-Hodgkin } \\
\text { lymphoma }\end{array}$ & $\begin{array}{l}\text { Axicabtagene } \\
\text { ciloleucel (Yescarta) }\end{array}$ & $\begin{array}{l}\text { Formerly known as KTE-C19. } \\
\text { CART19 product composed of } \\
\text { an extracellular CD19 targeting } \\
\text { scFv fused to CD28 and CD3z } \\
\text { intracellular signaling domains }\end{array}$ & 18th October 2017 & $(44,141)$ \\
\hline
\end{tabular}

a major role in alleviating the antitumor response where it can downregulate CD8 + effector $\mathrm{T}$ cell function and upregulates Treg maturation (156).

Modification of $\mathrm{T}$ cell receptors (TCR) is another approach for ACT and it is known as TCR transduced therapy. It is quite similar to CAR-T cells but their mechanisms for recognizing antigens are quite different. In CAR-T cells, antibody fragments are employed to bind the specific antigens on the surface of cancer cells. In contrast, TCRs use heterodimers consisting of alpha and beta-peptide chains to recognize polypeptide fragments presented by MHC molecules (157). This allows recognition of an intracellular, cell surface antigen or a neo-antigen produced by tumor cells after mutation. The TCR-T cell therapy directly modifies TCR binding to tumor antigens with high-affinity by genetic engineering technology (158). Therefore, it requires the identification of specific targets on cancer cells to ensure minimal off-target effects and cross-reactivity in other cells.
In TCR-T cell therapy, the MHC-dependent allows more antigen targeting compared to CARs. These antigens include MART-1, Gp100, CEA, NY-ESO-1, MAGE-A3, MAGE-A4, and others, which are suitable for TCR-T cell therapy (Table 5). In addition, TCR can also be targeted toward neoantigens generated by random mutations in tumor DNA and cancer-testis antigens (159).

Normally, the affinity of human TCRs toward cancer antigens is relatively low, which makes it impossible to recognize and kill tumors effectively. With the advance of engineering technology, genetically-modified TCR is encoded in T cells that give it better specificity and affinity toward cancer antigen. For example in the multiple myeloma patients, TCR was engineered through modifications of several key amino acids in order to have a higher affinity for cancer antigens, NY-ESO-1 (165). The clinical trial showed that $80 \%$ of these patients had a good clinical response while $70 \%$ of them had a complete or near-complete 
TABLE 5 | Current clinical trials of TCR-T therapy for solid tumors with reported outcomes.

\begin{tabular}{|c|c|c|c|c|c|c|}
\hline Target & Disease & $\begin{array}{l}\text { Clinical trial } \\
\text { number }\end{array}$ & Phase & Response & Country & References \\
\hline MART-1 & $\begin{array}{l}\text { Metastatic } \\
\text { melanoma }\end{array}$ & NCT00091104 & $\|$ & $\begin{array}{l}30 \% \text { objective antitumor } \\
\text { response }\end{array}$ & United States & (160) \\
\hline Gp100 & $\begin{array}{l}\text { Metastatic } \\
\text { melanoma }\end{array}$ & NCT00923195 & II (completed) & $\begin{array}{l}19 \% \text { objective antitumor } \\
\text { response }\end{array}$ & United States & (160) \\
\hline CEA & $\begin{array}{l}\text { Metastatic } \\
\text { colorectal }\end{array}$ & NCT00923806 & I (Terminated) & $\begin{array}{l}\text { Decreases in serum CEA levels } \\
(74-99 \%) \text { and one patient had } \\
\text { an objective regression. Severe } \\
\text { transient inflammatory colitis all } \\
\text { three patients. }\end{array}$ & United States & (143) \\
\hline NY-ESO-1 & $\begin{array}{l}\text { Metastatic } \\
\text { melanoma/synovial } \\
\text { cell sarcoma }\end{array}$ & NCT00670748 & । & $\begin{array}{l}2 \text { complete remission, } 1 \text { partial } \\
\text { remission }\end{array}$ & United States & (161) \\
\hline NY-ESO-1 & Multiple myeloma & NCT01352286 & $\|$ & $\begin{array}{l}80 \% \text { remission Objective } \\
\text { response was } 80 \% \text { at day } 42 . \\
\text { At year } 1,52 \% \text { of patients were } \\
\text { disease progression-free, } 11 \\
\text { were responders. No fatal } \\
\text { serious adverse events. }\end{array}$ & United States & (162) \\
\hline MAGE-A3 & $\begin{array}{l}\text { Metastatic } \\
\text { melanoma/multiple } \\
\text { myeloma }\end{array}$ & $\begin{array}{l}\text { NCT01350401 and } \\
\text { NCT01352286 }\end{array}$ & III/IV & 2 dies for cardiac toxicity & United States & (163) \\
\hline MAGE-A4 & Esophageal cancer & $\begin{array}{l}\text { Registered in the } \\
\text { UMIN Clinical Trials } \\
\text { Registry as ID: } \\
\text { UMIN000002395. }\end{array}$ & I & $7 / 10$ tumor regression & Japan & (164) \\
\hline
\end{tabular}

TABLE 6 | FDA approved and clinical trial cancer vaccines (78).

\begin{tabular}{|c|c|c|c|c|}
\hline Types of vaccine & $\begin{array}{l}\text { Trade name, } \\
\text { manufacturer }\end{array}$ & Indication/Study details & FDA approval date & $\begin{array}{l}\text { References/Clinical trial } \\
\text { identifier }\end{array}$ \\
\hline Attenuated bacteria & $\begin{array}{l}\text { BCG Live (TICE, Merck) } \\
\text { Previously (TheraCys }{ }^{\circledast} \text {, } \\
\text { Sanofi) }\end{array}$ & $\begin{array}{l}\text { - Treatment and prophylaxis of } \\
\text { carcinoma in situ (CIS) of the urinary } \\
\text { bladder. } \\
\text { - Prophylaxis of primary or recurrent } \\
\text { state Ta and/or T1 papillary tumors } \\
\text { following transurethral resection (TUR). }\end{array}$ & $\begin{array}{l}\text { TheraCys - } 21 \text { May } 1990 . \\
\text { TICE- } 16 \text { December } 2010\end{array}$ & $(172,173,194)$ \\
\hline Oncolytic virotherapy & $\begin{array}{l}\text { Talimogene laherparepvec } \\
\text { (IMLYGIC, Amgen Inc.) }\end{array}$ & $\begin{array}{l}\text { - Local treatment of unresectable } \\
\text { cutaneous, subcutaneous, and nodal } \\
\text { lesions in patients with melanoma } \\
\text { recurrent after the initial surgery. }\end{array}$ & 27 October 2015 & $(43,199,200)$ \\
\hline Peptide vaccines & $\begin{array}{l}\text { CEA and mammary type } \\
\text { mucin (MUC1), } \\
\text { (PANVAC-V/F) }\end{array}$ & $\begin{array}{l}\text { - PANVAC-V and PANVAC-F plus } \\
\text { sargramostim vaccination among } \\
\text { metastatic CRC versus non-CRC, } \\
\text { breast and ovarian cohorts }\end{array}$ & $\begin{array}{l}\text { Phase I clinical trial } \\
\text { completed }\end{array}$ & NCT00088413 \\
\hline
\end{tabular}

response (165). Another example is TCR-T cell therapy toward MART-1 for the treatment of metastatic melanoma patients. Results in clinical trials showed higher antitumor reactivity with objective cancer regressions were seen in 30 and 19\% of patients who received the human or mouse TCR, respectively. However, patients suffered some acceptable side effects without CRS (160). These findings show that $\mathrm{T}$ cells expressing highly reactive TCRs could mediate cancer regression in humans and target rare cognate-antigen-containing cells throughout the body. This is an important implication for the gene therapy of cancer. 
TABLE 7 | FDA and EMA approved cytokines drugs for various cancer treatments.

\begin{tabular}{|c|c|c|c|c|}
\hline Cytokines & Trade name, manufacturer & FDA approval date & Type of cancer treated & References \\
\hline \multirow[t]{2}{*}{ Recombinant interleukin (IL)-2 } & Aldesleukin, (Proleukin, Chiron) & 1992 & 1. Metastatic melanoma & $(209,210)$ \\
\hline & & & 2. Renal cell carcinoma (RCC) & \\
\hline \multirow[t]{3}{*}{ Recombinant alpha $2 \mathrm{a}$} & IFN- $\alpha 2$ a (Roferon ${ }^{\oplus}$-A, Roche) & 1986 & 1. Hairy cell lymphoma & $(210-212)$ \\
\hline & & & 2. Chronic myelogenous leukemia (CML) & \\
\hline & & & 3. Melanoma (not successful due to toxicity) & \\
\hline \multirow[t]{6}{*}{ Recombinant alpha $2 b$} & IFN- $\alpha 2 b\left(\right.$ Intron ${ }^{\circledR}-\mathrm{A}$, Merck) & 1986 & 1. AIDS-related Kaposi's sarcoma & $(213-216)$ \\
\hline & & & 2. Melanoma & \\
\hline & & & 3. Follicular lymphoma & \\
\hline & & & 4. Multiple myeloma & \\
\hline & & & 5. Hairy cell leukemia & \\
\hline & & & 6. Cervical intraepithelial neoplasm & \\
\hline
\end{tabular}

TABLE 8 | The type of novel trends in the immunotherapy with their advantages and drawbacks.

\begin{tabular}{|c|c|c|c|}
\hline No. & Types of immunotherapy & Advantages & Drawbacks \\
\hline 1 & $\begin{array}{l}\text { Monoclonal antibodies } \\
\text { (mAbs) }\end{array}$ & $\begin{array}{l}\text { - Relatively cost-effective among all of the other types, } \\
\text { therefore it is highly reproducible. } \\
\text { - Commercializable } \\
\text { - High specificity toward targeted antigens } \\
\text { - Effective in treating various types of cancers, regardless of } \\
\text { hematological malignancies or solid tumors }\end{array}$ & $\begin{array}{l}\text { - Labor intensive in order to determine the potential } \\
\text { immunotherapeutic targets. } \\
\text { - Short half-life mAbs may be less effective after some time } \\
\text { - Some cells produce high protein level and these cells may } \\
\text { escape from T cells and survive in the host }\end{array}$ \\
\hline 2 & $\begin{array}{l}\text { Immune checkpoint } \\
\text { inhibitors (ICls) }\end{array}$ & $\begin{array}{l}\text { - Relatively sensitive. Therefore, only minimum doses } \\
\text { required for each patient } \\
\text { - High specificity toward targeted inhibitors } \\
\text { - May enhance patient's T cell function through the activation } \\
\text { mechanism prior blockade } \\
\text { - Works best with combination treatment which may increase } \\
\text { its efficacy }\end{array}$ & $\begin{array}{l}\text { - The adverse effect such as systemic toxicity is most likely } \\
\text { to occur among patients } \\
\text { - Not all of the patients may respond toward ICl as some of } \\
\text { their T cells are unable to identify and kill malignant cells }\end{array}$ \\
\hline 3 & Vaccine & $\begin{array}{l}\text { - Vaccine goes direct to the tumor upon introduced } \\
\text { (localized) }\end{array}$ & $\begin{array}{l}\text { - Potential of rejection due to the introduction of foreign } \\
\text { materials }\end{array}$ \\
\hline 4 & Oncolytic virus & $\begin{array}{l}\text { - The virus only replicates in malignant cells thus lead to } \\
\text { apoptosis whereas no virus will be survived in normal cells } \\
\text { as they perform virus killing mechanism }\end{array}$ & - Efficacy may be reduced due to anti-viral immunity \\
\hline 5 & $\begin{array}{l}\text { Adoptive cell transfer } \\
\text { (Chimeric antigen receptor } \\
\text { CAR T cells) }\end{array}$ & $\begin{array}{l}\text { - Personalized toward each patient } \\
\text { - Works better among hematological malignancies patients } \\
\text { as CAR T cells may prolong the remission among these } \\
\text { group of patients }\end{array}$ & $\begin{array}{l}\text { - Expensive procedures } \\
\text { - Very technical, require highly skilled staff }\end{array}$ \\
\hline & & $\begin{array}{l}\text { - Have immune memory features due to permanent } \\
\text { modification done toward the T cells. }\end{array}$ & $\begin{array}{l}\text { - Prone to cytotoxicity toward hosts such as GvHD, CRS and } \\
\text { B-cell aplasia }\end{array}$ \\
\hline 6 & Cytokines & $\begin{array}{l}\text { - Earliest approaches in immunotherapy and FDA approved } \\
\text { drugs } \\
\text { - It is small in size makes it easier to interfere and disturb } \\
\text { cancer cells division } \\
\text { - Helps in boosting patients' immune system function thus } \\
\text { promotes T cells to kill the malignant cells effectively }\end{array}$ & $\begin{array}{l}\text { - Prone to cytotoxicity (cytokine storm) among patients due } \\
\text { to excess cytokine level }\end{array}$ \\
\hline
\end{tabular}

The reported outcomes of clinical TCR-T cell therapies are listed in Table 5. The first report on TCR-T cell therapy in colon cancer was targeting CEA antigens where some evidence of clinical response was seen but with severe colitis due to the presence of CEA in normal cells in the colon (143). This demonstrates the feasibility of T-cell therapy in metastatic colon cancer, but also the limitations of targeting CEA as an antigen. Following the promising results, another attempt was developed for treating advanced metastatic colon cancer patients. This was using mRNA-engineered T Cells targeting transforming growth factor $\beta$ - receptor type II (TGF $\beta$ II) frameshift antigen which is expressed in microsatellite instability positive (MSI+) colon cancer (166). However, the clinical trial was terminated due to severe adverse effects. Other ongoing TCR therapies are against KRAS G12V + tumor (NCT03190941) and KRAS G12D + tumor (NCT03745326), both are at clinical trials phase I/II (166).

$\mathrm{T}$ cell receptors therapy although it is a very promising approach comes with many challenges including good targets 
selection, specific TCRs search, optimal TCR affinity screening, safety evaluation, time and cost (159). In addition, since TCR therapy is highly dependent on MHC for peptide presentation, it may escape immune surveillance due to the downregulation or mutation of MHC molecules in the tumor environment, resulting in clinical limitations. Furthermore, hybridization (mismatch) between exogenous and endogenous chains may occur and induce harmful recognition of self-antigens, leading to graftversus-host disease (167). Although higher TCR affinity offers a great benefit, there is a possible risk of false targeting. In a nutshell, TCR-T cell therapy has shown some therapeutic potential but there are still many limitations that should be considered carefully.

\section{Cancer Vaccines}

Cancer cells express altered self-antigens that induce weaker responses compared to foreign antigens such as infectious agents. Often, immune stimulants and adjuvant are incorporated together with the cancer vaccines to enhance the effects. Cancer vaccine includes autologous patient-derived immune cell vaccines, tumor antigen-expressing recombinant virus vaccines, peptide vaccines, DNA vaccines and heterologous whole-cell vaccines derived from established human tumor cell lines (168).

Preventive (prophylactic) and therapeutic are the approaches of cancer vaccines treatments in which preventive cancer vaccines intended to minimize cancer incidence, morbidity and mortality while therapeutic vaccines aimed to treat current malignancies and may prevent $(169,170)$. To date, there are three FDA approved therapeutic cancer vaccines (Table 6).

The first FDA approved cancer vaccine was TheraCys ${ }^{\circledR}$ (Sanofi) (171). It is an intravesical, attenuated Connaught strain of Bacillus Calmette-Guarin (BCG) derived from Mycobacterium Bovis. TheraCys ${ }^{\circledR}$ is used in the treatment and prophylaxis of urothelial carcinoma-in situ (CIS), particularly non-muscle invasive bladder cancer (NMIBC) subtype. Results showed that approximately $74 \%$ of the patients showed a complete response with BCG compared to Doxorubicin (172). This vaccine also improves the protection against superficial bladder cancer recurrence. A randomized trial demonstrated that $70 \%$ of the CIS patients have a complete response to BCG therapy instead of doxorubicin suggesting the effectiveness of this vaccine compare to chemotherapy (173). At the start, two BCG strains were available; Connaught (TheraCys ${ }^{\circledR}$, Sanofi) and Tice (TICE ${ }^{\circledR}$, Merck). However, due to the supply shortage of TheraCys ${ }^{\circledR}$, it was discontinued and replaced by $\mathrm{TICE}^{\circledR}$. Nevertheless, a study conducted previously shows that treatments using different BCG strains among NMIBC patients have a significant role as BCG Connaught treatment was more effective than BCG Tice in terms of 5 years recurrence-free survival rate (174). Furthermore, a cohort study among 2099 NMIBC patients using both strains indicates that Connaught was more effective than Tice among patients without BCG maintenance (175).

Another FDA approved therapeutic vaccine is SipuleucelT (Provenge; Dendreon) which used to treat prostate cancer patients who are asymptomatic or minimally symptomatic metastatic castration-resistant. This vaccine uses the patient's own immune cells (dendritic cells, T cells, B cells and natural killer cells) isolated through leukapheresis. The immune cells were cultured and incubated with PA2024, a fusion protein made up of prostatic acid phosphatase (PAP) which is linked to granulocyte-macrophage colony-stimulating factor (GM-CSF) as the adjuvant $(41,176)$. Antigen-MHC complex was presented on activated DCs surface during incubation thus inducing CD4+ and CD8+ cells to act against PAP while GM-CSF improves DCs maturation upon being introduced into patients (177). This vaccine also shows significant survival benefit (50\% higher than in control) for this population of asymptomatic patients who have not been treated with chemotherapy, except for docetaxel (whose inherent toxicities often lead patients and physicians to delay administration until symptoms develop) (42). Currently approaches to enhance efficacy are considered to increase the efficiency of Sipuleucel-T in a wider range of patients. A study to look at the adverse effects related to the usage of this vaccine was performed and an adverse event spectrum was consistent with no new safety concerns observed from 2010 to 2017 (178).

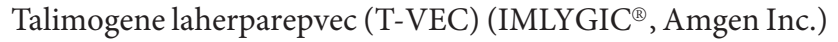
is the latest FDA approved vaccine to treat unresectable cutaneous, subcutaneous, and nodal lesions melanoma recurrent before initial surgery (179). T-VEC is a genetically modified oncolytic virotherapy made up of herpes simplex virus type I (HSV-1) (180). Significantly higher (16.3\%) durable response rate (DRR) was demonstrated among unresected stage IIIB to IV melanoma patients injected with T-VEC compared to GM-CSF (2.1\%) (43). A randomized trial among advance and unresectable melanoma patients revealed that combination therapy of T-VEC and ipilimumab have a significantly higher (39\%) objective response rate compared to ipilimumab only $(18 \%)$ due to their substantial activity $(181,182)$.

\section{CRC Cancer Vaccines}

To date, there are no CRC cancer vaccines approved by the FDA. Most of them are still undergoing clinical trials. Many studies are looking at various attractive, overexpressed single and combination uses of TAAs such as CEA (183-185), MAGE (186, $187)$, and MUC1 $(188,189)$. One of the cancer vaccine examples is the Poxviral vaccine regimen which targets TAAs such as CEA and MUC-1 using TRICOM vaccination strategy. In this approach, poxviruses are used as a viral vector for targeting CEA and MUC-1 in combination with T-cell co-stimulatory molecules (B7-1, ICAM-1, and LFA-3). The addition of the co-stimulatory molecules has been shown to greatly enhance the immune response to the antigen $(170,184,190)$. The recombinant poxviruses were engineered to express both signal 1 (antigen) and signal 2 (co-stimulatory molecules), with each transgene being driven by a different poxvirus promoter. Preclinical studies have demonstrated that when a TAA transgene is placed into a poxvirus genome, its expression leads to a more vigorous host T-cell immune response to the TAA than would be achieved otherwise (191). Approximately $56 \%$ of the metastatic carcinoma patients showed a significant immune response toward MUC1 and/or CEA following this vaccination $(184,190)$. In a phase I clinical trial of PANVAC-V, PANVAC-F and sargramostim (GM-CSF immunostimulator), this type of vaccine is associated with enhancing immune responses and has shown evidence of 
clinical activity among advanced CRC versus non-CRC, breast and ovarian carcinoma cohort.

Another peptide-based cancer vaccine targets CEA only. The study which was conducted using transgenic mice has shown that immunization with CEA peptides can elicit an immune response to kill cancer cells and hence may improve survival (192). Vaccination with an anti-CEA can break immune tolerance to TAA CEA and induce anti-CEA antibodies as well as CEA-specific $\mathrm{CD}^{+}{ }^{+}$T-helper responses in colon cancer patients and mice transgenic for human CEA (193). Furthermore, combination strategies with the CTL peptides of CEA to get both CDT-helper and CTL responses in the transgenic CEA/HLA-A2 mouse model have shown overall significant immune responses and survival (192). The combined vaccination strategy results in the potential use of this vaccination strategy for future clinical applications.

\section{Cytokines}

Cytokines are a group of small cell-signaling polypeptides with a molecular weight of less than $30 \mathrm{kDa}$ (204). They are secreted by various cells mainly the immune cells ( $\mathrm{T}$ cells, neutrophils and macrophages), endothelial cells, fibroblasts, and other stromal cells (205). There are more than 130 cytokines with various roles. However, their main function is similar which is to stimulate and modulate robust immune responses toward inflammations and infections (206). Besides, these glycoproteins can act on the cells that produce them (autocrine action), in adjacent cells (paracrine action) or in distant cells (endocrine action) (207).

Cytokines are one of the potential polypeptides used in immunotherapy since they can enhance patients' immune responses well. Three recombinant cytokines such as recombinant interferon-alpha and interleukin-2 drugs have been approved by the FDA and EMA for the treatment of several malignancies (Table 7) (208). A renewed interest in the anti-tumor properties of cytokines has led to an exponential increase in the number of clinical trials that explore the safety

\section{REFERENCES}

1. Bray F, Ferlay J, Soerjomataram I, Siegel RL, Torre LA, Jemal A. Global cancer statistics 2018: GLOBOCAN estimates of incidence and mortality worldwide for 36 cancers in 185 countries. CA Cancer J Clin. (2018) 68:394-424. doi: 10.3322/caac. 21492

2. Ferlay J, Ervik M, Lam F, Colombet M, Mery L, Piñeros M, et al. Global Cancer Observatory: Cancer Today. (2019). Available online at: https://gco.iarc.fr/ today/data/factsheets/cancers/10_8_9-Colorectum-fact-sheet.pdf (accessed September 21, 2019).

3. Siegel RL, Miller KD, Fedewa SA, Ahnen DJ, Meester RGS, Barzi A, et al. Colorectal cancer statistics, 2017. CA Cancer J Clin. (2017) 67:177-93. doi: 10.3322/caac. 21395

4. Arnold M, Sierra MS, Laversanne M, Soerjomataram I, Jemal A, Bray F. Global patterns and trends in colorectal cancer incidence and mortality. Gut. (2016) 66:683-91. doi: 10.1136/gutjnl-2015-31 0912

5. Schmoll HJ, Van Cutsem E, Stein A, Valentini V, Glimelius B, Haustermans $\mathrm{K}$, et al. ESMO consensus guidelines for management of patients with colon and rectal cancer. A personalized approach to clinical decision making. Ann Oncol. (2012) 23:2479-516. doi: 10.1093/annonc/mds236 and efficacy of cytokine-based drugs, not only as single agents but also in combination with other immunomodulatory drugs. These second-generation drugs under clinical development include known molecules with novel mechanisms of action, new targets, and fusion proteins that increase the half-life and target cytokine activity to the tumor microenvironment or the desired effector immune cells. In addition, the detrimental activity of immunosuppressive cytokines can be blocked by antagonistic antibodies, small molecules, cytokine traps or siRNAs.

\section{SUMMARY}

In this review, we provide an overview of the novel trends in the immunotherapy field that are yielding therapeutic benefits in CRC patients. We summarize the advantages and drawbacks of each type of immunotherapy in Table 8. The future for immunotherapy is vast with different approaches. What it takes is smart strategies in overcoming the evasion of cancer cells from immune recognition.

\section{AUTHOR CONTRIBUTIONS}

NJ and NS contributed to the conception and design of the study. NS wrote the first draft of the manuscript, looked for the raw material and summarize the findings, and constructed the diagrams and tables. NJ did the final editing and final input of ideas. Both authors contributed to manuscript revision, read and approved the submitted version.

\section{FUNDING}

This work was supported by the Ministry of Energy, Science, Technology, Environment and Climate Change (MESTECC) Malaysia, under Science Fund, grant number: 02-01-02-SF1329.

6. Van Cutsem E, Cervantes A, Nordlinger B, Arnold D. Metastatic colorectal cancer: ESMO clinical practice guidelines for diagnosis, treatment and follow-up. Ann Oncol. (2014) 25(Suppl. 3):iii1-9. doi: 10.1093/annonc/ mdu260

7. Yoshino T, Arnold D, Taniguchi H, Pentheroudakis G, Yamazaki K, Xu RH, et al. Pan-Asian adapted ESMO consensus guidelines for the management of patients with metastatic colorectal cancer: A JSMO-ESMO initiative endorsed by CSCO, KACO, MOS, SSO and TOS. Ann Oncol. (2018) 29:4470. doi: 10.1093/annonc/mdx738

8. Van Cutsem E, Cervantes A, Adam R, Sobrero A, Van Krieken JH, Aderka $\mathrm{D}$, et al. ESMO consensus guidelines for the management of patients with metastatic colorectal cancer. Ann Oncol. (2016) 27:1386-422. doi: 10.1093/ annonc/mdw235

9. Bonjer HJ, Deijen CL, Abis GA, Cuesta MA, Van der Pas MHGM, De Lange-de Klerk ESM, et al. A randomized trial of laparoscopic versus open surgery for rectal cancer. N Engl J Med. (2015) 372:1324-32. doi: 10.1056/ NEJMoa1414882

10. MacFarlane JK, Ryall RDH, Heald RJ. Mesorectal excision for rectal cancer. Lancet. (1993) 341:457-60. doi: 10.1016/0140-6736(93)90207-W

11. Park SC, Sohn DK, Kim MJ, Chang HJ, Han KS, Hyun JH, et al. Phase II clinical trial to evaluate the efficacy of transanal endoscopic total mesorectal 
excision for rectal cancer. Dis Colon Rectum. (2018) 61:554-60. doi: 10.1097/ DCR. 0000000000001058

12. Miller KD, Nogueira L, Mariotto AB, Rowland JH, Yabroff KR, Alfano CM, et al. Cancer treatment and survivorship statistics, 2019. CA Cancer J Clin. (2019) 0:1-23. doi: 10.3322/caac.21565

13. Garg MB, Lincz LF, Adler K, Scorgie FE, Ackland SP, Sakoff JA. Predicting 5-fluorouracil toxicity in colorectal cancer patients from peripheral blood cell telomere length: a multivariate analysis. Br J Cancer. (2012) 107:1525-33. doi: 10.1038/bjc.2012.421

14. González-Perera I, Gutiérrez-Nicolás F, Nazco-Casariego GJ, Ramos-Diaz R, Hernández-San GR, Pérez-Pérez JA, et al. 5-fluorouracil toxicity in the treatment of colon cancer associated with the genetic polymorphism 2846 A > G (rs67376798). J Oncol Pharm Pract. (2017) 23:396-8. doi: 10.1177/ 1078155216647202

15. Ogura A, Konishi T, Cunningham C, Garcia-Aguilar J, Iversen H, Toda S, et al. Neoadjuvant (Chemo)radiotherapy with total mesorectal excision only is not sufficient to prevent lateral local recurrence in enlarged nodes: results of the multicenter lateral node study of patients with low cT3/4 rectal cancer. J Clin Oncol. (2018) 37:33-43. doi: 10.1200/JCO

16. Gajewski TF, Schreiber H, Fu YX. Innate and adaptive immune cells in the tumor microenvironment. Nat Immunol. (2013) 14:1014-22. doi: 10.1038/ni. 2703

17. Marcus A, Gowen BG, Thompson TW, Iannello A, Ardolino M, Deng W, et al. Recognition of tumors by the innate immune system and natural killer cells. Adv Immunol. (2014) 122:91-128. doi: 10.1016/B978-0-12-800267-4. 00003-1

18. Vesely MD, Kershaw MH, Schreiber RD, Smyth MJ. Natural innate and adaptive immunity to cancer. Annu Rev Immunol. (2011) 29:235-71. doi: 10.1146/annurev-immunol-031210-101324

19. Im A, Pavletic SZ. Immunotherapy in hematologic malignancies: past, present, and future. J Hematol Oncol. (2017) 10:1-10. doi: 10.1186/s13045017-0453-8

20. Nixon NA, Blais N, Ernst S, Kollmannsberger C, Bebb G, Butler M, et al. Current landscape of immunotherapy in the treatment of solid tumours, with future opportunities and challenges. Curr Oncol. (2018) 25:e373-84. doi: $10.3747 /$ co. 25.3840

21. Fehleisen F. Ueber die züchtung der erysipelkokken auf künstlichem nåhrboden und ihre uebertragbarkeit auf den menschen. Dtsch Med Wochenschr. (1882) 8:553-4. doi: 10.1055/s-0029-1196806

22. Busch W. Aus der sitzung der medicinischen section vom 13 November 1867. Berlin Klin Wochenschr. (1868) 5:137.

23. Coley WB. II. Contribution to the knowledge of sarcoma. Ann Surg. (1891) 14:199-220. doi: 10.1097/00000658-189112000-00015

24. McCarthy EF. The toxins of William B. Coley and the treatment of bone and soft-tissue sarcomas. Iowa Orthop J. (2006) 26:154-8.

25. Nikolaou M, Nikolaou G, Digklia A, Pontas C, Tsoukalas N, Kyrgias G, et al. Immunotherapy of cancer: Developments and reference points, an unorthodox approach. Integr Cancer Ther. (2019) 18:1-10. doi: 10.1177/ 1534735419827090

26. Coley WB. The treatment of inoperable sarcoma by bacterial toxins (The mixed toxins of the Streptococcus erysipelas and the Bacillus prodigiosus). Proc R Soc Med. (1910) 3:1-48. doi: 10.1177/003591571000301601

27. Dobosz P, Dzieciątkowski T. The intriguing history of cancer immunotherapy. Front Immunol. (2019) 10:2965. doi: 10.3389/fimmu. 2019.02965

28. Burnet FM. The concept of immunological surveillance. Prog Exp Tumor Res. (1970) 13:1-27. doi: 10.1159/000386035

29. Burnet M. Immunological factors in the process of carcinogenesis. $\mathrm{Br} \mathrm{Med}$ Bull. (1964) 20:154-8. doi: 10.1093/oxfordjournals.bmb.a070310

30. Klein G, Sjogren HO, Klein E, Hellstrom KE. Demonstration of resistance against methylcholanthrene-induced sarcomas in the primary autochthonous host. Cancer Res. (1960) 20:1561-72.

31. Isaacs A, Lindenmann J. Virus interference. I. The interferon. Proc R Soc London Ser B Biol Sci. (1957) 147:258-67. doi: 10.1098/rspb.1957.0048

32. Graham JB, Graham RM. The effect of vaccine on cancer patients. Surg Gynecol Obstet. (1959) 109:131-8. doi: 10.1097/00006534-19591100000016
33. Miller JFAP, Mitchell GF, Weiss NS. Cellular basis of the immunological defects in thymectomized mice. Nature. (1967) 214:992-7. doi: 10.1038/ 214992a0

34. Steinman RM, Cohn ZA. Identification of a novel cell type in peripheral lymphoid organs of mice: I. Morphology, quantitation, tissue distribution. J Exp Med. (1973) 137:1142-62. doi: 10.1084/jem.137.5.1142

35. Kiessling R, Klein E, Wigzell H. Natural killer cells in the mouse. I. Cytotoxic cells with specificity for mouse Moloney leukemia cells. Specificity and distribution according to genotype. Eur J Immunol. (1975) 5:112-7. doi: 10.1002/eji.1830050208

36. Kiessling R, Klein E, Pross H, Wigzell H. Natural killer cells in the mouse. II. Cytotoxic cells with specificity for mouse Moloney leukemia cells. Characteristics of the killer cell. Eur J Immunol. (1975) 5:117-21. doi: 10. 1002/eji. 1830050209

37. Köhler G, Milstein C. Continuous cultures of fused cells secreting antibody of predefined specificity. Nature. (1975) 256:495-7. doi: 10.1038/256495a0

38. Brunet JF, Denizot F, Luciani MF, Roux-Dosseto M, Suzan M, Mattei MG, et al. A new member of the immunoglobulin superfamily-CTLA-4. Nature. (1988) 328:267-70. doi: 10.1038/328267a0

39. Maloney DG, Grillo-Lopez AJ, White CA, Bodkin D, Schilder RJ, Neidhart JA, et al. IDEC-C2B8 (Rituximab) anti-CD20 monoclonal antibody therapy in patients with relapsed low-grade non-Hodgkin's lymphoma. Blood. (1997) 90:2188-95.

40. Rosenberg SA, Lotze MT, Yang JC, Topalian SL, Chang AE, Schwartzentruber DJ, et al. Prospective randomized trial of high-dose interleukin-2 alone or in conjunction with lymphokine-activated killer cells for the treatment of patients with advanced cancer. JNCI J Natl Cancer Inst. (1993) 85:622-32. doi: 10.1093/jnci/85.8.622

41. Cheever MA, Higano CS. PROVENGE (Sipuleucel-T) in prostate cancer: the first FDA-approved therapeutic cancer vaccine. Clin Cancer Res. (2011) 17:3520-6. doi: 10.1158/1078-0432.CCR-10-3126

42. Kantoff PW, Higano CS, Shore ND, Berger ER, Small EJ, Penson DF, et al. Sipuleucel-T immunotherapy for castration-resistant prostate cancer. $N$ Engl J Med. (2010) 363:411-22. doi: 10.1056/NEJMoa1001294

43. Andtbacka RHI, Kaufman HL, Collichio F, Amatruda T, Senzer N, Chesney $\mathrm{J}$, et al. Talimogene laherparepvec improves durable response rate in patients with advanced melanoma. J Clin Oncol. (2015) 33:2780-8. doi: 10.1200/JCO. 2014.58.3377

44. Neelapu SS, Locke FL, Bartlett NL, Lekakis LJ, Miklos DB, Jacobson $\mathrm{CA}$, et al. Axicabtagene ciloleucel CAR T-cell therapy in refractory large B-Cell lymphoma. N Engl J Med. (2017) 377:2531-44. doi: 10.1056/ NEJMoa1707447

45. Schuster SJ, Bishop MR, Tam CS, Waller EK, Borchmann P, McGuirk JP, et al. Tisagenlecleucel in adult relapsed or refractory diffuse large B-Cell lymphoma. N Engl J Med. (2019) 380:45-56. doi: 10.1056/NEJMoa1804980

46. Guo ZS. The 2018 Nobel Prize in medicine goes to cancer immunotherapy (editorial for BMC cancer). BMC Cancer. (2018) 18:1086. doi: 10.1186/ s12885-018-5020-3

47. Galluzzi L, Vacchelli E, Bravo-San Pedro JM, Buque A, Senovilla L, Baracco EE, et al. Classification of current anticancer immunotherapies. Oncotarget. (2014) 5:12472-508. doi: 10.18632/oncotarget.2998

48. Brekke OH, Sandlie I. Therapeutic antibodies for human diseases at the dawn of the twenty-first century. Nat Rev Drug Discov. (2003) 2:52-62. doi: $10.1038 / \mathrm{nrd} 984$

49. Köhler G, Milstein C. Derivation of specific antibody-producing tissue culture and tumor lines by cell fusion. Eur J Immunol. (1976) 6:511-9. doi: 10.1002/eji.1830060713

50. Smith GP. Filamentous fusion phage: novel expression vectors that display cloned antigens on the virion surface. Science. (1985) 228:1315-7. doi: 10. 1126/science.4001944

51. Kurosawa K, Lin W, Ohta K. Chimeric antibodies. Methods Mol Biol. (2014) 1060:139-48. doi: 10.1007/978-1-62703-586-6_8

52. Lu RM, Hwang YC, Liu IJ, Lee CC, Tsai HZ, Li HJ, et al. Development of therapeutic antibodies for the treatment of diseases. J Biomed Sci. (2020) 27:1-30. doi: 10.1186/s12929-019-0592-z

53. Kettleborough CA, Saldanha J, Heath VJ, Morrison CJ, Bendig MM. Humanization of a mouse monoclonal antibody by CDR-grafting: the 
importance of framework residues on loop conformation. Protein Eng. (1991) 4:773-83. doi: 10.1093/protein/4.7.773

54. Hansel TT, Kropshofer H, Singer T, Mitchell JA, George AJT. The safety and side effects of monoclonal antibodies. Nat Rev Drug Discov. (2010) 9:325-38. doi: $10.1038 / \mathrm{nrd} 3003$

55. Lipman NS, Jackson LR, Trudel LJ, Weis-Garcia F. Monoclonal versus polyclonal antibodies: distinguishing characteristics, applications, and information resources. ILAR Journal. (2005) 46:258-68. doi: 10.1093/ilar.46. 3.258

56. Bubeník J, Barešová $M$, Viklický V, Jakoubková J, Sainerová $\mathrm{H}$, Donner J. Established cell line of urinary bladder carcinoma (T24) containing tumourspecific antigen. Int J Cancer. (1973) 11:765-73. doi: 10.1002/ijc.2910110327

57. Hollinshead A, Elias EG, Arlen M, Buda B, Mosley M, Scherrer J. Specific active immunotherapy in patients with adenocarcinoma of the colon utilizing tumor-associated antigens (TAA). A phase I clinical trial. Cancer. (1985) 56:480-9. doi: 10.1002/1097-0142(19850801)56:33.0.co;2-2

58. Dickinson JP, Caspary EA, Field EJ. A common tumour specific antigen. $\mathrm{Br} \mathrm{J}$ Cancer. (1973) 27:99-105. doi: 10.1038/bjc.1973.13

59. Speetjens FM, Kuppen PJK, Welters MJP, Essahsah F, Van Den Brink AMEGV, Lantrua MGK, et al. Induction of p53-specific immunity by a p53 synthetic long peptide vaccine in patients treated for metastatic colorectal cancer. Clin Cancer Res. (2009) 15:1086-95. doi: 10.1158/1078-0432.CCR08-2227

60. Alatrash G, Crain AK, Molldrem JJ. Tumor-Associated Antigens. Immune Biology of Allogeneic Hematopoietic Stem Cell Transplantation. Amsterdam: Elsevier (2019). p. 107-25. doi: 10.1016/B978-0-12-812630-1.00007-4

61. Cloosen S, Arnold J, Thio M, Bos GMJ, Kyewski B, Germeraad WTV. Expression of tumor-associated differentiation antigens, MUC1 glycoforms and CEA, in human thymic epithelial cells: implications for self-tolerance and tumor therapy. Cancer Res. (2007) 67:3919-26. doi: 10.1158/0008-5472. CAN-06-2112

62. Even-Desrumeaux K, Baty D, Chames P. State of the art in tumor antigen and biomarker discovery. Cancers (Basel). (2011) 3:2554-96. doi: 10.3390/ cancers3022554

63. Scanlan MJ, Gure AO, Jungbluth AA, Old LJ, Chen YT. Cancer/testis antigens: an expanding family of targets for cancer immunotherapy. Immunol Rev. (2002) 188:22-32. doi: 10.1034/j.1600-065X.2002.18803.x

64. Kerkar SP, Wang ZF, Lasota J, Park T, Patel K, Groh E, et al. MAGE-A is more highly expressed than NY-ESO-1 in a systematic immunohistochemical analysis of 3668 cases. J Immunother. (2016) 39:181-7. doi: 10.1097/CJI. 0000000000000119

65. Yanagi T, Nagai K, Shimizu H, Matsuzawa SI. Melanoma antigen A12 regulates cell cycle via tumor suppressor p21 expression. Oncotarget. (2017) 8:68448-59. doi: 10.18632/oncotarget.19497

66. Santha Kumara HMC, Grieco MJ, Caballero OL, Su T, Ahmed A, Ritter E, et al. MAGE-A3 is highly expressed in a subset of colorectal cancer patients. Cancer Immun. (2012) 12:1-9.

67. Nicolazzo C, Raimondi C, Francescangeli F, Ceccarelli S, Trenta P, Magri V, et al. EpCAM-expressing circulating tumor cells in colorectal cancer. Int $J$ Biol Markers. (2017) 32:e415-20. doi: 10.5301/ijbm.5000284

68. Starzynska T, Marsh PJ, Schofield PF, Roberts SA, Myers KA, Stern PL. Prognostic significance of 5T4 oncofetal antigen expression in colorectal carcinoma. Br J Cancer. (1994) 69:899-902. doi: 10.1038/bjc.1994.173

69. Besneux M, Greenshields-Watson A, Scurr MJ, MacLachlan BJ, Christian A, Davies MM, et al. The nature of the human $\mathrm{T}$ cell response to the cancer antigen $5 \mathrm{~T} 4$ is determined by the balance of regulatory and inflammatory $\mathrm{T}$ cells of the same antigen-specificity: Implications for vaccine design. Cancer Immunol Immunother. (2019) 68:247-56. doi: 10.1007/s00262-018-2266-1

70. Wang W, Li Y, Zhang X, Jing J, Zhao X, Wang Y, et al. Evaluating the significance of expression of CEA mRNA and levels of CEA and its related proteins in colorectal cancer patients. J Surg Oncol. (2014) 109:440-4. doi: $10.1002 /$ jso. 23503

71. Bright RK, Bright JD, Byrne JA. Overexpressed oncogenic tumor-self antigens. Hum Vaccines Immunother. (2014) 10:3297-305. doi: 10.4161/hv. 29475

72. Liu J, Zhou Q, Xu J, Wang J, Zhang Y. Detection of EGFR expression in patients with colorectal cancer and the therapeutic effect of cetuximab. $J$ BUON. (2016) 21:95-100.
73. Geng W, Liang W, Fan Y, Ye Z, Zhang L. Overexpression of CCDC34 in colorectal cancer and its involvement in tumor growth, apoptosis and invasion. Mol Med Rep. (2018) 17:465-73. doi: 10.3892/mmr.2017.7860

74. Wang ZK, Cheng ZW, Chen SJ, Zhu XG, Gu YP, Yang XD, et al. Aberrant expression of Rab1A and its prognostic significance in human colorectal cancer. Eur Rev Med Pharmacol Sci. (2018) 22:4509-17. doi: 10.26355/ eurrev_201807_15505

75. Michaud HA, Eliaou JF, Lafont V, Bonnefoy N, Gros L. Tumor antigentargeting monoclonal antibody-based immunotherapy: orchestrating combined strategies for the development of long-term antitumor immunity. Oncoimmunology. (2014) 3:e955684. doi: 10.4161/21624011.2014.955684

76. Scott AM, Wolchok JD, Old LJ. Antibody therapy of cancer. Nat Rev Cancer. (2012) 12:278-87. doi: 10.1038/nrc3236

77. Biopharma LLC. BIOPHARMA ${ }^{\circledR}$ : Biopharmaceutical Products in the U.S. and European Markets. (2019). Available online at: www.biopharma.com (accessed June 26, 2019).

78. Food and Drug Administration. Resources for Information on Approved Drugs. (2019). Available online at: www.fda.gov/ drugs/informationondrugs/approveddrugs (accessed June 28, 2019).

79. European Medicines Agency. (2019). Available online at: www.ema.europa.eu/ema (accessed June 28, 2019).

80. Gonzalez H, Hagerling C, Werb Z. Roles of the immune system in cancer: From tumor initiation to metastatic progression. Genes Dev. (2018) 32:126784. doi: 10.1101/gad.314617.118

81. Pardoll D. Cancer and immune system: basic concepts and targets for intervention. Semin Oncol. (2015) 42:523-38. doi: 10.1053/j.seminoncol. 2015.05 .003

82. Seidel JA, Otsuka A, Kabashima K. Anti-PD-1 and Anti-CTLA-4 therapies in cancer: mechanisms of action, efficacy, and limitations. Front Oncol. (2018) 8:86. doi: $10.3389 /$ fonc. 2018.00086

83. Joller N, Kuchroo VK. Tim-3, Lag-3, and TIGIT. Curr Top Microbiol Immunol. (2017) 410:127-56. doi: 10.1007/82_2017_62

84. Kisielow M, Kisielow J, Capoferri-Sollami G, Karjalainen K. Expression of lymphocyte activation gene 3 (LAG-3) on B cells is induced by T cells. Eur J Immunol. (2005) 35:2081-8. doi: 10.1002/eji.200526090

85. Kong Y, Zhu L, Schell TD, Zhang J, Claxton DF, Ehmann WC, et al. T-cell immunoglobulin and ITIM domain (TIGIT) associates with CD8+ T-cell exhaustion and poor clinical outcome in AML patients. Clin Cancer Res. (2016) 22:3057-66. doi: 10.1158/1078-0432.CCR-15-2626

86. Monney L, Sabatos CA, Gaglia JL, Ryu A, Waldner H, Chernova T, et al. Th1-specific cell surface protein Tim-3 regulates macrophage activation and severity of an autoimmune disease. Nature. (2002) 415:536-41. doi: 10.1038/ 415536a

87. Menter DG, Davis JS, Broom BM, Overman MJ, Morris J, Kopetz S. Back to the colorectal cancer consensus molecular subtype future. Curr Gastroenterol Rep. (2019) 21:1-12. doi: 10.1007/s11894-019-0674-9

88. Rodriguez-Salas N, Dominguez G, Barderas R, Mendiola M, García-Albéniz $\mathrm{X}$, Maurel J, et al. Clinical relevance of colorectal cancer molecular subtypes. Crit Rev Oncol Hematol. (2017) 109:9-19. doi: 10.1016/j.critrevonc.2016. 11.007

89. Shemirani AI, Haghighi MM, Zadeh SM, Fatemi SR, Taleghani MY, Zali N, et al. Simplified MSI marker panel for diagnosis of colorectal cancer. Asian Pac J Cancer Prev. (2011) 12:2101-4. doi: 10.17179/excli2018-1455

90. Kawakami H, Zaanan A, Sinicrope FA. Microsatellite instability testing and its role in the management of colorectal cancer. Curr Treat Options Oncol. (2015) 16:1-15. doi: 10.1007/s11864-015-0348-2

91. Nojadeh JN, Behrouz Sharif S, Sakhinia E. Microsatellite instability in colorectal cancer. EXCLI J. (2018) 17:159-68. doi: 10.17179/excli2017-948

92. Giannakis M, Mu XJ, Shukla SA, Qian ZR, Cohen O, Nishihara R, et al. Genomic correlates of immune-cell infiltrates in colorectal carcinoma. Cell Rep. (2016) 15:857-65. doi: 10.1016/j.celrep.2016.03.075

93. Overman MJ, Lonardi S, Wong KYM, Lenz HJ, Gelsomino F, Aglietta M, et al. Durable clinical benefit with nivolumab plus ipilimumab in DNA mismatch repair-deficient/microsatellite instability-high metastatic colorectal cancer. J Clin Oncol. (2018) 36:773-9. doi: 10.1200/JCO.2017.76.9901

94. Krummel MF, Allison JP. CD28 and CTLA-4 have opposing effects on the response of T cells to stimulation. J Exp Med. (1995) 182:459-65. doi: 10. 1084/jem.182.2.459 
95. Sanchez-Lockhart M, Rojas AV, Fettis MM, Bauserman R, Higa TR, Miao H, et al. T cell receptor signaling can directly enhance the avidity of CD28 ligand binding. PLoS One (2014) 9:e89263. doi: 10.1371/journal.pone.0089263

96. Ward SG. CD28: a signalling perspective. Biochem J. (1996) 318:361-77. doi: 10.1042/bj318036

97. Buchbinder EI, Desai A. CTLA-4 and PD-1 pathways similarities, differences, and implications of their inhibition. Am J Clin Oncol Cancer Clin Trials. (2016) 39:98-106. doi: 10.1097/COC.0000000000000239

98. Chambers CA, Kuhns MS, Egen JG, Allison JP. CTLA-4-mediated inhibition in regulation of $\mathrm{T}$ cell responses: mechanisms and manipulation in tumor immunotherapy. Annu. Rev. Immunol. (2001) 19:565-94. doi: 10.1146/ annurev.immunol.19.1.565

99. Egen JG, Kuhns MS, Allison JP. CTLA-4: New insights into its biological function and use in tumor immunotherapy. Nat Immunol. (2002) 3:611-8. doi: 10.1038/ni0702-611

100. Intlekofer AM, Thompson CB. At the bench: Preclinical rationale for CTLA-4 and PD-1 blockade as cancer immunotherapy. J Leukoc Biol. (2013) 94:25-39. doi: $10.1189 /$ jlb.1212621

101. Jørgensen N, Persson G, Hviid TVF. The tolerogenic function of regulatory T cells in pregnancy and cancer. Front Immunol. (2019) 10:1-21. doi: 10.3389/ fimmu.2019.00911

102. Liakou CI, Kamat A, Tang DN, Chen H, Sun J, Troncoso P, et al. CTLA-4 blockade increases IFNgamma-producing CD4+ICOShi cells to shift the ratio of effector to regulatory T cells in cancer patients. Proc Natl Acad Sci USA. (2008) 105:14987-92. doi: 10.1073/pnas.0806075105

103. Lee HT, Lee SH, Heo YS. Molecular interactions of antibody drugs targeting PD-1, PD-L1, and CTLA-4 in immuno-oncology. Molecules. (2019) 4:1-16. doi: 10.3390/molecules24061190

104. Pernot S, Terme M, Voron T, Colussi O, Marcheteau E, Tartour E, et al. Colorectal cancer and immunity: what we know and perspectives. World $J$ Gastroenterol. (2014) 20:3738-50. doi: 10.3748/wjg.v20.i14.3738

105. Ishida $T$, Ishii $T$, Inagaki $A$, Yano $H$, Komatsu $H$, Iida $S$, et al. Specific recruitment of $\mathrm{CC}$ chemokine receptor 4-positive regulatory $\mathrm{T}$ cells in Hodgkin lymphoma fosters immune privilege. Cancer Res. (2006) 66:571622. doi: 10.1158/0008-5472.CAN-06-0261

106. Shinohara T, Taniwaki M, Ishida Y, Kawaichi M, Honjo T. Structure and chromosomal localization of the human PD-1 gene (PDCD1). Genomics. (1994) 23:704-6. doi: 10.1006/geno.1994.1562

107. Agata Y, Kawasaki A, Nishimura H, Ishida Y, Tsubata T, Yagita H, et al. Expression of the PD-1 antigen on the surface of stimulated mouse $\mathrm{T}$ and B lymphocytes. Int Immunol. (1996) 8:765-72. doi: 10.1093/intimm/ 8.5.765

108. Kitano A, Ono M, Yoshida M, Noguchi E, Shimomura A, Shimoi T, et al. Tumour-infiltrating lymphocytes are correlated with higher expression levels of PD-1 and PD-L1 in early breast cancer. ESMO Open. (2017) 2:e000150. doi: 10.1136/esmoopen-2016-000150

109. Yamazaki T, Akiba H, Iwai H, Matsuda H, Aoki M, Tanno Y, et al. Expression of programmed death 1 ligands by murine T Cells and APC. J Immunol. (2002) 169:5538-45. doi: 10.4049/jimmunol.169.10.5538

110. Pardoll DM. The blockade of immune checkpoints in cancer immunotherapy. Nat Rev Cancer. (2012) 12:252-64. doi: 10.1038/nrc3239

111. Latchman Y, Wood CR, Chernova T, Chaudhary D, Borde M, Chernova I, et al. PD-L2 is a second ligand for PD-1 and inhibits T cell activation. Nat Immunol. (2001) 2:261-8. doi: 10.1038/85330

112. Terawaki S, Chikuma S, Shibayama S, Hayashi T, Yoshida T, Okazaki T, et al. IFN- $\alpha$ directly promotes programmed cell death-1 transcription and limits the duration of T cell-mediated immunity. J Immunol. (2011) 186:2772-9. doi: 10.4049/jimmunol.1003208

113. Shindo Y, Yoshimura K, Kuramasu A, Watanabe Y, Ito H, Kondo T, et al. Combination immunotherapy with 4-1BB activation and PD-1 blockade enhances antitumor efficacy in a mouse model of subcutaneous tumor. Anticancer Res. (2015) 35:129-36.

114. Dong Y, Sun Q, Zhang X. PD-1 and its ligands are important immune checkpoints in cancer. Oncotarget. (2017) 8:2171-86. doi: 10.18632/ oncotarget.13895

115. Henick BS, Herbst RS, Goldberg SB. The PD-1 pathway as a therapeutic target to overcome immune escape mechanisms in cancer. Expert Opin Ther Targets. (2014) 18:1407-20. doi: 10.1517/14728222.2014.955794
116. Gong J, Chehrazi-Raffle A, Reddi S, Salgia R. Development of PD-1 and PDL1 inhibitors as a form of cancer immunotherapy: a comprehensive review of registration trials and future considerations. J Immunother Cancer. (2018) 6:1-18. doi: 10.1186/s40425-018-0316-Z

117. Patnaik A, Kang SP, Rasco D, Papadopoulos KP, Elassaiss-Schaap J, Beeram $\mathrm{M}$, et al. Phase I study of pembrolizumab (MK-3475; Anti-PD-1 monoclonal antibody) in patients with advanced solid tumors. Clin Cancer Res. (2015) 21:4286-93. doi: 10.1158/1078-0432.CCR-14-2607

118. Reck M, Rodriguez-Abreu D, Robinson AG, Hui R, Csöszi T, Fülöp A, et al. Pembrolizumab versus chemotherapy for PD-L1-positive nonsmall-cell lung cancer. N Engl J Med. (2016) 375:1823-33. doi: 10.1056/ NEJMoa1606774

119. Le DT, Uram JN, Wang H, Bartlett BR, Kemberling H, Eyring AD, et al. PD-1 blockade in tumors with mismatch-repair deficiency. N Engl J Med. (2015) 372:2509-20. doi: 10.1056/NEJMoa1500596

120. Overman MJ, McDermott R, Leach JL, Lonardi S, Lenz HJ, Morse MA, et al. Nivolumab in patients with metastatic DNA mismatch repair-deficient or microsatellite instability-high colorectal cancer (CheckMate 142): an openlabel, multicentre, phase 2 study. Lancet Oncol. (2017) 18:1182-91. doi: 10. 1016/S1470-2045(17)30422-9

121. Tran KQ, Zhou J, Durflinger KH, Langhan MM, Shelton TE, Wunderlich JR, et al. Minimally cultured tumor-infiltrating lymphocytes display optimal characteristics for adoptive cell therapy. J Immunother. (2008) 31:742-51. doi: 10.1097/CJI.0b013e31818403d5

122. Benmebarek MR, Karches CH, Cadilha BL, Lesch S, Endres S, Kobold S. Killing mechanisms of chimeric antigen receptor (CAR) T cells. Int J Mol Sci. (2019) 20:1283. doi: 10.3390/ijms20061283

123. Rosenberg SA, Packard BS, Aebersold PM, Solomon D, Topalian SL, Toy ST, et al. Use of tumor-infiltrating lymphocytes and interleukin-2 in the immunotherapy of patients with metastatic melanoma. N Engl J Med. (1988) 319:1676-80. doi: 10.1056/NEJM198812223192527

124. Morgan RA, Dudley ME, Wunderlich JR, Hughes MS, Yang JC, Sherry RM, et al. Cancer regression in patients after transfer of genetically engineered lymphocytes. Science. (2006) 314:126-9. doi: 10.1126/science.1129003

125. Kershaw MH, Westwood JA, Parker LL, Wang G, Eshhar Z, Mavroukakis SA, et al. A phase I study on adoptive immunotherapy using gene-modified $\mathrm{T}$ cells for ovarian cancer. Clin Cancer Res. (2006) 12(20 Pt 1):6106-15. doi: 10.1158/1078-0432.CCR-06-1183

126. Lamers CHJ, Willemsen R, Van Elzakker P, Van Steenbergen-Langeveld S, Broertjes M, Oosterwijk-Wakka J, et al. Immune responses to transgene and retroviral vector in patients treated with ex vivo-engineered T cells. Blood. (2011) 117:72-82. doi: 10.1182/blood-2010-07-294520

127. Ramos CA, Dotti G. Chimeric antigen receptor (CAR)-engineered lymphocytes for cancer therapy. Expert Opin Biol Ther. (2011) 11:855-73. doi: $10.1517 / 14712598.2011 .573476$

128. Wang X, Rivière I. Clinical manufacturing of CAR T cells: foundation of a promising therapy. Mol Ther Oncolytics. (2016) 3:1-7. doi: 10.1038/mto. 2016.15

129. Bishop MR, Maziarz RT, Waller EK, Jäger U, Westin JR, McGuirk JP, et al. Tisagenlecleucel in relapsed/refractory diffuse large B-cell lymphoma patients without measurable disease at infusion. Blood Adv. (2019) 3:2230-6. doi: 10.1182/bloodadvances.2019000151

130. Pituch KC, Miska J, Krenciute G, Panek WK, Li G, Rodriguez-Cruz T, et al. Adoptive transfer of IL13R $\alpha 2$-specific chimeric antigen receptor T cells creates a pro-inflammatory environment in glioblastoma. Mol Ther. (2018) 26:986-95. doi: 10.1016/j.ymthe.2018.02.001

131. Miao H, Choi BD, Suryadevara CM, Sanchez-Perez L, Yang S, De Leon G, et al. EGFRvIII-specific chimeric antigen receptor T cells migrate to and kill tumor deposits infiltrating the brain parenchyma in an invasive xenograft model of glioblastoma. PLoS One. (2014) 9:e94281. doi: 10.1371/journal. pone.0094281

132. Lázaro-Gorines R, Ruiz-de-la-Herrán J, Navarro R, Sanz L, Álvarez-Vallina L, Martínez-del-Pozo A, et al. A novel carcinoembryonic antigen (CEA)targeted trimeric immunotoxin shows significantly enhanced antitumor activity in human colorectal cancer xenografts. Sci Rep. (2019) 9:11680. doi: 10.1038/s41598-019-48285-z

133. Sadelain M, Rivière I, Riddell S. Therapeutic T cell engineering. Nature. (2017) 545:423-31. doi: 10.1038/nature22395 
134. Tang XY, Sun Y, Zhang A, Hu GL, Cao WW, Dan H, et al. Third-generation CD28/4-1BB chimeric antigen receptor $\mathrm{T}$ cells for chemotherapy relapsed or refractory acute lymphoblastic leukaemia: a non-randomised, open-label phase I trial protocol. BMJ Open. (2016) 6:e013904. doi: 10.1136/bmjopen2016-013904

135. Ali SA, Shi V, Maric I, Wang M, Stroncek DF, Rose JJ, et al. T cells expressing an anti-B-cell maturation antigen chimeric antigen receptor cause remissions of multiple myeloma. Blood. (2016) 128:1688-700. doi: 10.1182/blood-201604-711903

136. Perica K, Varela JC, Oelke M, Schneck J. Adoptive T cell immunotherapy for cancer. Rambam Maimonides Med J. (2015) 6:e0004. doi: 10.5041/RMMJ. 10179

137. Morgan RA, Chinnasamy N, Abate-Daga D, Gros A, Robbins PF, Zheng $\mathrm{Z}$, et al. Cancer regression and neurological toxicity following anti-MAGEA3 TCR gene therapy. J Immunother. (2013) 36:133-51. doi: 10.1097/CJI. 0b013e3182829903

138. Lee DW, Gardner R, Porter DL, Louis CU, Ahmed N, Jensen M, et al. Current concepts in the diagnosis and management of cytokine release syndrome. Blood. (2014) 124:188-95. doi: 10.1182/blood-2014-05-552729

139. Maude SL, Laetsch TW, Buechner J, Rives S, Boyer M, Bittencourt H, et al. Tisagenlecleucel in children and young adults with B-cell lymphoblastic leukemia. N Engl J Med. (2018) 378:439-48. doi: 10.1056/NEJMoa1709866

140. Pehlivan KC, Duncan BB, Lee DW. CAR-T cell therapy for acute lymphoblastic leukemia: Transforming the treatment of relapsed and refractory disease. Curr Hematol Malig Rep. (2018) 13:396-406. doi: 10.1007/ s11899-018-0470-x

141. Locke FL, Neelapu SS, Bartlett NL, Siddiqi T, Chavez JC, Hosing CM, et al. Phase 1 Results of ZUMA-1: a multicenter study of KTE-C19 anti-CD19 CAR T cell therapy in refractory aggressive lymphoma. Mol Ther. (2017) 25:285-95. doi: 10.1016/j.ymthe.2016.10.020

142. Magee MS, Abraham TS, Baybutt TR, FlickingerJr JC, Ridge NA, Marszalowicz GP, et al. Human GUCY2C-targeted chimeric antigen receptor (CAR)-expressing $\mathrm{T}$ cells eliminate colorectal cancer metastases. Cancer Immunol Res. (2018) 6:509-16. doi: 10.1158/2326-6066.CIR-160362

143. Parkhurst MR, Yang JC, Langan RC, Dudley ME, Nathan DAN, Feldman $\mathrm{SA}$, et al. T cells targeting carcinoembryonic antigen can mediate regression of metastatic colorectal cancer but induce severe transient colitis. Mol Ther. (2011) 19:620-6. doi: 10.1038/mt.2010.272

144. Hege KM, Bergsland EK, Fisher GA, Nemunaitis JJ, Warren RS, McArthur JG, et al. Safety, tumor trafficking and immunogenicity of chimeric antigen receptor (CAR)-T cells specific for TAG-72 in colorectal cancer. J Immunother Cancer. (2017) 5:1-14. doi: 10.1186/s40425-0170222-9

145. Zhang BL, Li D, Gong YL, Huang Y, Qin DY, Jiang L, et al. Preclinical evaluation of chimeric antigen receptor-modified T cells specific to epithelial cell adhesion molecule for treating colorectal cancer. Hum Gene Ther. (2019) 30:402-12. doi: 10.1089/hum.2018.229

146. Deng X, Gao F, Li N, Li Q, Zhou Y, Yang T, et al. Antitumor activity of NKG2D CAR-T cells against human colorectal cancer cells in vitro and in vivo. Am J Cancer Res. (2019) 9:945-58.

147. Bonifant CL, Jackson HJ, Brentjens RJ, Curran KJ. Toxicity and management in CAR T-cell therapy. Mol Ther Oncolytics. (2016) 3:1-7. doi: 10.1038/mto. 2016.11

148. Martinez M, Moon EK. CAR T cells for solid tumors: new strategies for finding, infiltrating, and surviving in the tumor microenvironment. Front Immunol. (2019) 10:128. doi: 10.3389/fimmu.2019.00128

149. Abbasi AM, Chester KA, MacPherson AJ, Boxer GM, Begent RH, Malcolm $\mathrm{AD}$. Localization of CEA messenger RNA by in situ hybridization in normal colonic mucosa and colorectal adenocarcinomas. J Pathol. (1992) 168:405-11. doi: 10.1002/path.1711680411

150. Zhang C, Wang Z, Yang Z, Wang M, Li S, Li Y, et al. Phase I escalating-dose trial of CAR-T therapy targeting CEA + metastatic colorectal cancers. Mol Ther. (2017) 25:1248-58. doi: 10.1016/j.ymthe.2017.03.010

151. Chi X, Yang P, Zhang E, Jieyi G, Hui X, Li M, et al. Significantly increased anti-tumor activity of carcinoembryonic antigen-specific chimeric antigen receptor $\mathrm{T}$ cells in combination with recombinant human $\mathrm{IL}-12$. Cancer Med. (2019) 8:4753-65. doi: 10.1002/cam4.2361
152. Wang G, Lu X, Dey P, Deng P, Wu CC, Jiang S, et al. Targeting YAPdependent MDSC infiltration impairs tumor progression. Cancer Discov. (2016) 6:80-95. doi: 10.1158/2159-8290.CD-15-0224

153. Feig C, Jones JO, Kraman M, Wells RJB, Deonarine A, Chan DS, et al. Targeting CXCL12 from FAP-expressing carcinoma-associated fibroblasts synergizes with anti-PD-L1 immunotherapy in pancreatic cancer. Proc Natl Acad Sci USA. (2013) 110:20212-7. doi: 10.1073/pnas.1320318110

154. Kershaw MH, Wang G, Westwood JA, Pachynski RK, Tiffany HL, Marincola $\mathrm{FM}$, et al. Redirecting migration of T cells to chemokine secreted from tumors by genetic modification with CXCR2. Hum Gene Ther. (2002) 13:1971-80. doi: $10.1089 / 10430340260355374$

155. Crespo J, Sun H, Welling TH, Tian Z, Zou WT. cell anergy, exhaustion, senescence, and stemness in the tumor microenvironment. Curr Opin Immunol. (2013) 25:214-21. doi: 10.1016/j.coi.2012.12.003

156. Ma S, Li X, Wang X, Cheng L, Li Z, Zhang C, et al. Current progress in CAR-T cell therapy for solid tumors. Int J Biol Sci. (2019) 15:2548-60. doi: 10.7150/ijbs.34213

157. Xu Y, Yang Z, Horan LH, Zhang P, Liu L, Zimdahl B, et al. A novel antibody-TCR (AbTCR) platform combines Fab-based antigen recognition with gamma/delta-TCR signaling to facilitate T-cell cytotoxicity with low cytokine release. Cell Discov. (2018) 4:1-13. doi: 10.1038/s41421-0180066-6

158. Barrett DM, Grupp SA, June CH. Chimeric antigen receptor- and TCRModified T cells enter main street and wall street. J Immunol. (2015) 195:755-61. doi: 10.4049/jimmunol.1500751

159. Garber K. Driving T-cell immunotherapy to solid tumors. Nat Biotechnol. (2018) 36:215-9. doi: 10.1038/nbt.4090

160. Johnson LA, Morgan RA, Dudley ME, Cassard L, Yang JC, Hughes MS, et al. Gene therapy with human and mouse T-cell receptors mediates cancer regression and targets normal tissues expressing cognate antigen. Blood. (2009) 114:535-46. doi: 10.1182/blood-2009-03-211714

161. Robbins PF, Morgan RA, Feldman SA, Yang JC, Sherry RM, Dudley ME, et al. Tumor regression in patients with metastatic synovial cell sarcoma and melanoma using genetically engineered lymphocytes reactive with NY-ESO1. J Clin Oncol. (2011) 29:917-24. doi: 10.1200/JCO.2010.32.2537

162. Stadtmauer EA, Faitg TH, Lowther DE, Badros AZ, Chagin K, Dengel K, et al. Long-term safety and activity of NY-ESO-1 SPEAR T cells after autologous stem cell transplant for myeloma. Blood Adv. (2019) 3:2022-34. doi: 10.1182/bloodadvances.2019000194

163. Linette GP, Stadtmauer EA, Maus MV, Rapoport AP, Levine BL, Emery L, et al. Cardiovascular toxicity and titin cross-reactivity of affinity-enhanced T cells in myeloma and melanoma. Blood. (2013) 122:863-71. doi: 10.1182/ blood-2013-03-490565

164. Kageyama S, Ikeda H, Miyahara Y, Imai N, Ishihara M, Saito K, et al. Adoptive transfer of MAGE-A4 T-cell receptor gene-transduced lymphocytes in patients with recurrent esophageal cancer. Clin Cancer Res. (2015) 21:2268-77. doi: 10.1158/1078-0432.CCR-14-1559

165. Rapoport AP, Stadtmauer EA, Binder-Scholl GK, Goloubeva O, Vogl DT, Lacey SF, et al. NY-ESO-1-specific TCR-engineered T cells mediate sustained antigen-specific antitumor effects in myeloma. Nat Med. (2015) 21:914-21. doi: $10.1038 / \mathrm{nm} .3910$

166. ClinicalTrials.gov. (2020). Available online at: https://clinicaltrials.gov/ct2/ home (accessed May 31, 2020).

167. Zhao L, Cao YJ. Engineered T cell therapy for cancer in the clinic. Front Immunol. (2019) 10:2250. doi: 10.3389/fimmu.2019.02250

168. Thomas S, Prendergast GC. Cancer vaccines: a brief overview. In: Thomas S editor. Methods in Molecular Biology. (Vol. 1403), New York, NY: Humana Press Inc (2016). p. 755-61. doi: 10.1007/978-1-4939-3387-7_43

169. Lollini PL, Cavallo F, Nanni P, Quaglino E. The promise of preventive cancer vaccines. Vaccines. (2015) 3:467-89. doi: 10.3390/vaccines3020467

170. Schlom J, Hodge JW, Palena C, Tsang KY, Jochems C, Greiner JW. Therapeutic cancer vaccines. Adv Cancer Res. (2014) 121:67-124. doi: 10. 1016/B978-0-12-800249-0.00002-0

171. DeMaria PJ, Bilusic M. Cancer vaccines. Hematol Oncol Clin North Am. (2019) 33:199-214. doi: 10.1016/j.hoc.2018.12.001

172. Barreto L, Csizer Z, Sparkes JD. Evaluation of clinical data in bladder cancer immunotherapy with Connaught BCG (ImmuCyst). Dev Biol Stand. (1992) 77:229-31. 
173. Lamm DL, Blumenstein BA, Crawford, Montie JE, Scardino P, Grossman $\mathrm{HB}$, et al. A randomized trial of intravesical doxorubicin and immunotherapy with Bacille Calmette-Guérin for transitional-cell carcinoma of the bladder. N Engl J Med. (1991) 325:1205-9. doi: 10.1056/NEJM199110243251703

174. Rentsch CA, Birkhäuser FD, Biot C, Gsponer JR, Bisiaux A, Wetterauer C, et al. Bacillus Calmette-Guérin strain differences have an impact on clinical outcome in bladder cancer immunotherapy. Eur Urol. (2014) 66:677-88. doi: 10.1016/j.eururo.2014.02.061

175. Witjes JA, Dalbagni G, Karnes RJ, Shariat S, Joniau S, Palou J, et al. The efficacy of BCG TICE and BCG Connaught in a cohort of 2,099 patients with T1G3 non-muscle-invasive bladder cancer. Urol Oncol Semin Orig Investig. (2016) 34:484.e19-e25. doi: 10.1016/j.urolonc.2016.05.033

176. Graddis TJ, McMahan CJ, Tamman J, Page KJ, Trager JB. Prostatic acid phosphatase expression in human tissues. Int J Clin Exp Pathol. (2011) 4:295-306.

177. Hammerstrom AE, Cauley DH, Atkinson BJ, Sharma P. Cancer immunotherapy: sipuleucel-T and beyond. Pharmacotherapy. (2011) 31:813-28. doi: 10.1592/phco.31.8.813

178. Dores GM, Bryant-Genevier M, Perez-Vilar S. Adverse events associated with the use of sipuleucel-T reported to the US Food and Drug Administration's adverse event reporting system, 2010-2017. JAMA Netw Open. (2019) 2:e199249. doi: 10.1001/jamanetworkopen.2019.9249

179. Raman SS, Hecht JR, Chan E. Talimogene laherparepvec: review of its mechanism of action and clinical efficacy and safety. Immunotherapy. (2019) 11:705-23. doi: 10.2217/imt-2019-0033

180. Conry RM, Westbrook B, McKee S, Norwood TG. Talimogene laherparepvec: First in class oncolytic virotherapy. Hum Vaccines Immunother. (2018) 14:839-46. doi: 10.1080/21645515.2017.1412896

181. Chesney J, Puzanov I, Collichio F, Singh P, Milhem MM, Glaspy J, et al. Randomized, open-label phase II study evaluating the efficacy and safety of talimogene laherparepvec in combination with ipilimumab versus ipilimumab alone in patients with advanced, unresectable melanoma. J Clin Oncol. (2018) 36:1658-67. doi: 10.1200/JCO.2017.73.7379

182. Chesney J, Puzanov I, Collichio F, Milhem MM, Hauschild A, Chen L, et al. Patterns of response with talimogene laherparepvec in combination with ipilimumab or ipilimumab alone in metastatic unresectable melanoma. $\mathrm{Br}$ J Cancer. (2019) 121:417-20. doi: 10.1038/s41416-019-0530-6

183. Bilusic M, Heery CR, Arlen PM, Rauckhorst M, Apelian D, Tsang KY, et al. Phase I trial of a recombinant yeast-CEA vaccine (GI-6207) in adults with metastatic CEA-expressing carcinoma. Cancer Immunol Immunother. (2014) 63:225-34. doi: 10.1007/s00262-013-1505-8

184. Gulley JL, Arlen PM, Tsang KY, Yokokawa J, Palena C, Poole DJ, et al. Pilot study of vaccination with recombinant CEA-MUC-1-tricom pox viralbased vaccines in patients with metastatic carcinoma. Clin Cancer Res. (2008) 14:3060-9. doi: 10.1158/1078-0432.CCR-08-0126

185. Kaufman HL, Lenz HJ, Marshall J, Singh D, Garett C, Cripps C, et al. Combination chemotherapy and ALVAC-CEA/B7.1 vaccine in patients with metastatic colorectal cancer. Clin Cancer Res. (2008) 14:4843-9. doi: 10.1158/ 1078-0432.CCR-08-0276

186. Zhan W, Zhang Z, Zhang Y, Ma J, Wu T, Gu Y, et al. Prognostic value of MAGE-A9 expression in patients with colorectal cancer. Clin Res Hepatol Gastroenterol. (2016) 40:239-45. doi: 10.1016/J.CLINRE.2015. 08.005

187. Zhang QM, He SJ, Shen N, Luo B, Fan R, Fu J, et al. Overexpression of MAGE-D4 in colorectal cancer is a potentially prognostic biomarker and immunotherapy target. Int J Clin Exp Pathol. (2014) 7:3918-27.

188. Morse MA, Niedzwiecki D, Marshall JL, Garrett C, Chang DZ, Aklilu M, et al. A randomized phase II study of immunization with dendritic cells modified with poxvectors encoding CEA and MUC1 compared with the same poxvectors plus GM-CSF for resected metastatic colorectal cancer. Ann Surg. (2013) 258:879-86. doi: 10.1097/SLA.0b013e318292919e

189. Tang CK, Katsara M, Apostolopoulos V. Strategies used for MUC1 immunotherapy: human clinical studies. Expert Rev Vaccines. (2008) 7:96375. doi: 10.1586/14760584.7.7.963

190. DiPaola RS, Plante M, Kaufman H, Petrylak DP, Israeli R, Lattime E, et al. A phase I trial of pox PSA vaccines (PROSTVAC ${ }^{\circledR}$-VF) with B7-1, ICAM-1, and LFA-3 co-stimulatory molecules (TRICOM ${ }^{\mathrm{TM}}$ ) in patients with prostate cancer. J Transl Med. (2006) 4:1-5. doi: 10.1186/1479-5876-4-1
191. Hodge JW, McLaughlin JP, Kantor JA, Schlom J. Diversified prime and boost protocols using recombinant vaccinia virus and recombinant nonreplicating avian pox virus to enhance T-cell immunity and antitumor responses. Vaccine. (1997) 15:759-68. doi: 10.1016/s0264-410x(96)00238-1

192. Saha A, Chatterjee SK, Foon KA, Celis E, Bhattacharya-Chatterjee M. Therapy of established tumors in a novel murine model transgenic for human carcinoembryonic antigen and HLA-A2 with a combination of anti-idiotype vaccine and CTL peptides of carcinoembryonic antigen. Cancer Res. (2007) 67:2881-92. doi: 10.1158/0008-5472.CAN-06-3045

193. Hensel JA, Khattar V, Ashton R, Ponnazhagan S. Recombinant AAV-CEA tumor vaccine in combination with an immune adjuvant breaks tolerance and provides protective immunity. Mol Ther Oncolytics. (2019) 12:41-8. doi: 10.1016/j.omto.2018.12.004

194. Lamm DL. BCG immunotherapy for transitional-cell carcinoma in situ of the bladder. Oncology (Williston Park). (1995) 9:947-55.

195. Burch PA, Breen JK, Buckner JC, Gastineau DA, Kaur JA, Laus RL, et al. Priming tissue-specific cellular immunity in a phase I trial of autologous dendritic cells for prostate cancer. Clin Cancer Res. (2000) 6:2175-82.

196. Burch PA, Croghan GA, Gastineau DA, Jones LA, Kaur JS, Kylstra JW, et al. Immunotherapy (APC8015, provenge ${ }^{\circledR}$ ) targeting prostatic acid phosphatase can induce durable remission of metastatic androgen-independent prostate cancer: a phase 2 trial. Prostate. (2004) 60:197-204. doi: 10.1002/pros.20040

197. Small EJ, Schellhammer PF, Higano CS, Redfern CH, Nemunaitis JJ, Valone $\mathrm{FH}$, et al. Placebo-controlled phase III trial of immunologic therapy with sipuleucel-T (APC8015) in patients with metastatic, asymptomatic hormone refractory prostate cancer. J Clin Oncol. (2006) 24:3089-94. doi: 10.1200/JCO. 2005.04.5252

198. Beer TM, Bernstein GT, Corman JM, Glode LM, Hall SJ, Poll WL, et al. Randomized trial of autologous cellular immunotherapy with sipuleucel-T in androgen-dependent prostate cancer. Clin Cancer Res. (2011) 17:4558-67. doi: 10.1158/1078-0432.CCR-10-3223

199. Hu JCC, Coffin RS, Davis CJ, Graham NJ, Groves N, Guest PJ, et al. A phase I study of OncoVEX GM-CSF, a second-generation oncolytic herpes simplex virus expressing granulocyte macrophage colony-stimulating factor. Clin Cancer Res. (2006) 12:6737-47. doi: 10.1158/1078-0432.CCR-06-0759

200. Senzer NN, Kaufman HL, Amatruda T, Nemunaitis M, Reid T, Daniels G, et al. Phase II clinical trial of a granulocyte-macrophage colony-stimulating factor-encoding, second-generation oncolytic herpesvirus in patients with unresectable metastatic melanoma. J Clin Oncol. (2009) 27:5763-71. doi: 10.1200/JCO.2009.24.3675

201. Kantoff PW, Schuetz TJ, Blumenstein BA, Michael GL, Bilhartz DL, Wyand $\mathrm{M}$, et al. Overall survival analysis of a phase II randomized controlled trial of a poxviral-based PSA-targeted immunotherapy in metastatic castrationresistant prostate cancer. J Clin Oncol. (2010) 28:1099-105. doi: 10.1200/JCO. 2009.25.0597

202. Kantoff PW, Gulley JL, Pico-Navarro C. Revised overall survival analysis of a phase II, randomized, double-blind, controlled study of PROSTVAC in men with metastatic castration-resistant prostate cancer. J Clin Oncol. (2017) 35:124-5. doi: 10.1200/JCO.2016.69.7748

203. Gulley JL, Borre M, Vogelzang NJ, Ng S, Agarwal N, Parker CC, et al. Phase III trial of PROSTVAC in asymptomatic or minimally symptomatic metastatic castration-resistant prostate cancer. J Clin Oncol. (2019) 37:1051-61. doi: 10.1200/JCO.18.02031

204. Berraondo P, Sanmamed MF, Ochoa MC, Etxeberria I, Aznar MA, PérezGracia JL, et al. Cytokines in clinical cancer immunotherapy. $\mathrm{Br} J$ Cancer. (2019) 120:6-15. doi: 10.1038/s41416-018-0328-y

205. Rusch T, Bayry J, Werner J, Shevchenko I, Bazhin AV. Immunotherapy as an option for cancer treatment. Arch Immunol Ther Exp (Warsz). (2018) 66:89-96. doi: 10.1007/s00005-017-0491-5

206. Chen L, Deng H, Cui H, Fang J, Zuo Z, Deng J, et al. Inflammatory responses and inflammation-associated diseases in organs. Oncotarget. (2018) 9:720418. doi: 10.18632/oncotarget.23208

207. Ferreira VL, Borba HHL, Bonetti AF, Leonart LP, Pontarolo R. Cytokines and Interferons: Types and Functions. Autoantibodies and Cytokines. London: IntechOpen (2019). doi: 10.5772/intechopen.74550

208. García-Martínez E, Smith M, Buqué A, Aranda F, Peña FA, Ivars A, et al. Trial watch: immunostimulation with recombinant cytokines for cancer therapy. Oncoimmunology. (2018) 7:e1433982. doi: 10.1080/2162402X.2018.1433982 
209. McDermott DF, Cheng SC, Signoretti S, Margolin KA, Clark JI, Sosman JA, et al. The high-dose aldesleukin "select" trial: a trial to prospectively validate predictive models of response to treatment in patients with metastatic renal cell carcinoma. Clin Cancer Res. (2015) 21:561-8. doi: 10.1158/1078-0432. CCR-14-1520

210. Eigentler TK, Gutzmer R, Hauschild A, Heinzerling L, Schadendorf D, Nashan D, et al. Adjuvant treatment with pegylated interferon $\alpha-2$ a versus low-dose interferon $\alpha$-2a in patients with high-risk melanoma: a randomized phase III DeCOG trial. Ann Oncol. (2016) 27:1625-32. doi: 10.1093/annonc/ mdw225

211. Habermann TM, Andersen JW, Cassileth PA, Bennett JM, Oken MM. Sequential administration of recombinant interferon alpha and deoxycoformycin in the treatment of hairy cell leukaemia. Br J Haematol. (1992) 80:466-71. doi: 10.1111/j.1365-2141.1992.tb04559.x

212. Lipton JH, Khoroshko N, Golenkov A, Abdulkadyrov K, Nair K, Raghunadharao D, et al. Phase II, randomized, multicenter, comparative study of peginterferon- $\alpha-2 \mathrm{a}(40 \mathrm{kD})$ (Pegasys $\left.{ }^{\circledR}\right)$ versus interferon $\alpha$ 2a (Roferon ${ }^{\circledR}-\mathrm{A}$ ) in patients with treatment-naïve, chronic-phase chronic myelogenous leukemia. Leuk Lymphoma. (2007) 48:497-505. doi: 10.1080/ 10428190601175393

213. Biesma B, Willemse PHB, Mulder NH, Verschueren RCJ, Kema IP, de Bruijn HWA, et al. Recombinant interferon alpha- $2 \mathrm{~b}$ in patients with metastatic apudomas: effect on tumours and tumour markers. Br J Cancer. (1992) 66:850-5. doi: 10.1038/bjc.1992.372
214. Flanigan RC, Salmon SE, Blumenstein BA, Bearman SI, Roy V, McGrath PC, et al. Nephrectomy followed by interferon alfa- $2 \mathrm{~b}$ compared with interferon alfa-2b alone for metastatic renal-cell cancer. N Engl J Med. (2001) 345:16559. doi: 10.1056/NEJMoa003013

215. Michallet M, Maloisel F, Delain M, Hellmann A, Rosas A, Silver RT, et al. Pegylated recombinant interferon alpha- $2 \mathrm{~b}$ vs recombinant interferon alpha$2 \mathrm{~b}$ for the initial treatment of chronic-phase chronic myelogenous leukemia: A phase III study. Leukemia. (2004) 18:309-15. doi: 10.1038/sj.leu.240 3217

216. Yamazaki N, Uhara H, Wada H, Matsuda K, Yamamoto K, Shimamoto T, et al. Phase I study of pegylated interferon-alpha- $2 \mathrm{~b}$ as an adjuvant therapy in Japanese patients with malignant melanoma. J Dermatol. (2016) 43:1146-53. doi: $10.1111 / 1346-8138.13338$

Conflict of Interest: The authors declare that the research was conducted in the absence of any commercial or financial relationships that could be construed as a potential conflict of interest.

Copyright (c) 2020 Johdi and Sukor. This is an open-access article distributed under the terms of the Creative Commons Attribution License (CC BY). The use, distribution or reproduction in other forums is permitted, provided the original author(s) and the copyright owner(s) are credited and that the original publication in this journal is cited, in accordance with accepted academic practice. No use, distribution or reproduction is permitted which does not comply with these terms. 